\title{
Pharmaceutical efficacy of harmalol in inhibiting hepatocellular carcinoma
}

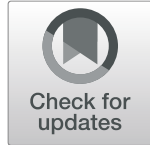

Sarita Sarkar², Paromita Bhattacharjee ${ }^{1}$, Tapas Ghosh ${ }^{1}$ and Kakali Bhadra ${ }^{*}$

\begin{abstract}
Background: Diethylnitrosamine (DEN) promoted by carbon tetrachloride $\left(\mathrm{CCl}_{4}\right)$ forms DNA adducts inducing hepatocellular carcinoma (HCC). Plant alkaloid, harmalol, is being used as a therapeutic agent against HCC due to its accessibility and efficacy by apoptosis and inhibiting proliferation of cancer epithelial cells.

Result: Seven groups of Swiss albino mice were taken. Different stages of liver tissues and serum from various experimental groups were collected before and after harmalol treatment. The investigation was carried out by enzyme assay, bilirubin level in the blood, DNA, RNA, normal serum protein of liver tissue, and alpha-feto protein estimation of serum. Gross morphological assessment of liver, histological, and different apoptosis markers viz. p53, caspase3, and cytochrome C expression were analyzed by RT-PCR and Western blot.

Harmalol (10 mg/kg B.W. per week, I.P.) for 9 weeks showed a significant reduction in hepatocellular foci, nodules, and carcinoma ultimately retaining the normal morphology. It further induces ROS-dependent apoptosis through mitochondrial cytochrome $\mathrm{C}$ release that induces $\mathrm{p} 53$ by caspase 3 activation.
\end{abstract}

Conclusion: The investigation will eventually help to develop more effective chemotherapeutic drugs from the natural source.

Keywords: Harmalol, Histology, DEN, CCl, HCC, Apoptosis, ROS, Caspase3, p53

\section{Background}

The liver is a key metabolic organ that is essential for the production of blood proteins, lipid and sugar metabolism, and detoxification of naturally occurring and foreign harmful chemicals. In Asia and Africa, hepatocarcinogenesis is one of the major causes of cancer deaths [1]. To maintain its mass and many essential functions, the liver possesses a remarkable regenerative capacity, but the latter also renders it highly susceptible to carcinogenesis. In fact, liver cancer often develops in the context of chronic liver injury [2]. The most common form of primary liver cancer, hepatocellular carcinoma (HCC), involves multistep processes which are correlated with different genetic alterations that ultimately lead to malignant transformation of the hepatocytes [3]. Among several liver cancer-inducing

\footnotetext{
* Correspondence: kakali_bhadra2004@yahoo.com

1 Department of Zoology, University of Kalyani, Nadia, West Bengal 741235, India

Full list of author information is available at the end of the article
}

agents, diethylnitrosamine (DEN) (Fig. 1a, inset) often induces malignant tumors in the target organ and is speciesspecific. DEN has been reported to cause the generation of ROS, forming DNA-carcinogen adducts in the liver and resulting in oxidative stress and cellular injury [4]. This potent genotoxic compound is widely found in the environment and present in tobacco smoke, varieties of food such as cheese, salted and dried fish, soybean, cured meat, alcoholic beverages, cosmetics, agricultural chemicals, several pharmaceutical agents, and ground water having a high level of nitrates making the human population vulnerable to its exposure and is also synthesized endogenously $[5,6]$. As preservatives, nitrites and nitrite salts are used in numerous foodstuffs in the food industry since 1920 to preserve the natural color of meat and the typical taste of processed, smoked, and cured meat and meat products. Meat proteins especially amines can react with the nitrites and produce $N$-nitrosamines [7]. As nitrosamine is found in food preservatives as an environmental 


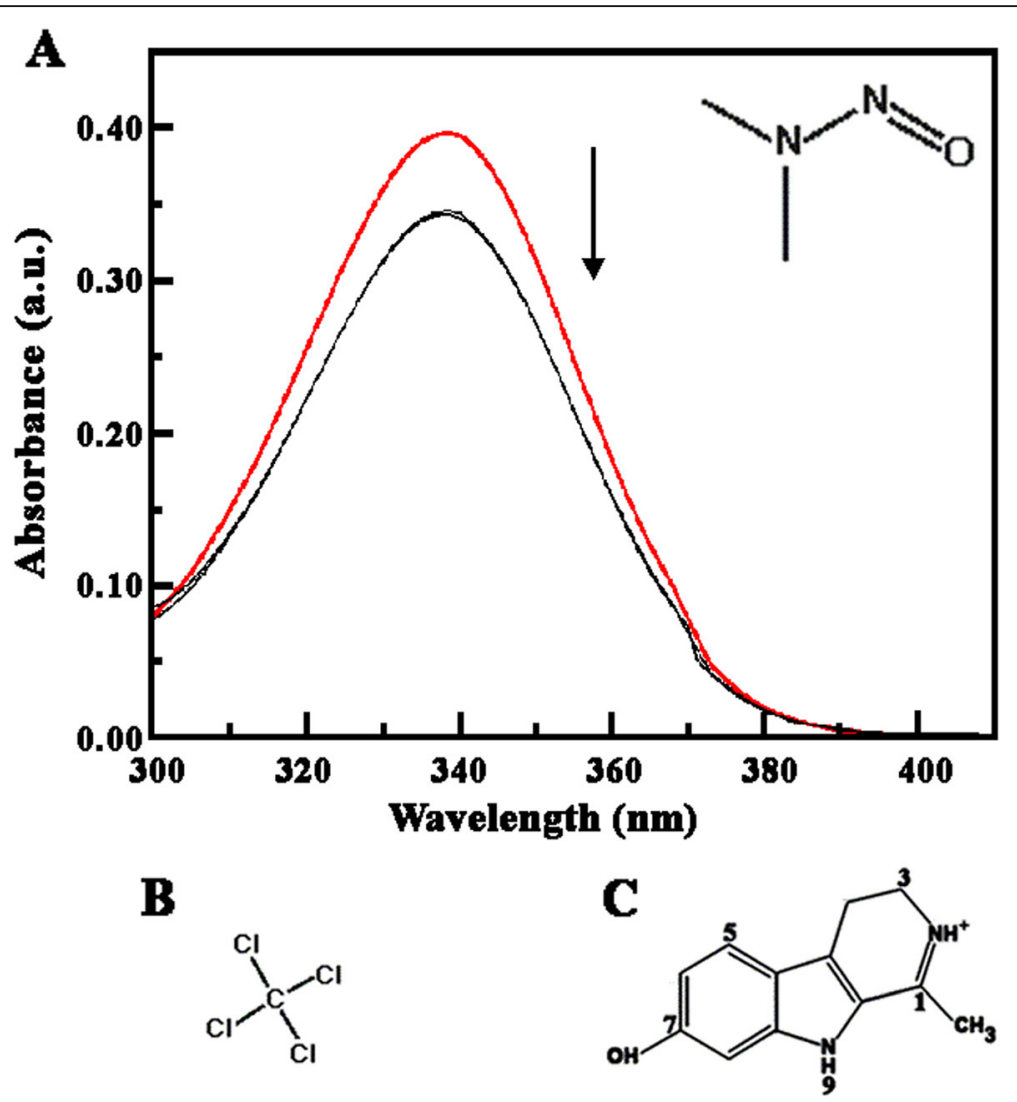

Fig. 1 A representative figure (top panel) showing the DNA-adduct formation by DEN upon titration with CT DNA. Chemical structure of a (inset) $\mathrm{DEN}, \mathbf{b} \mathrm{CCl}_{4}$, and $\mathbf{c}$ Harmalol

dietary carcinogen, an intensive study has been conducted on DEN induced hepatocarcinoma in a mouse model as a potent genotoxic agent $[8,9]$. Initially, rapid killing of hepatocytes was induced by DEN alone. But DEN by itself requires a long time to induce hepatocellular carcinoma but the assistance of tumor promoters like $\mathrm{CCl}_{4}$ ensures a shorter time span for the development of liver cancer [10]. Hence, this study concerns the application of DEN associated with $\mathrm{CCl}_{4}$ (Fig. 1b) to induce $\mathrm{HCC}$ in male Swiss albino mice model, which is again another potent hepatotoxin [11, 12]. Female mice have been reported to be resistant to HCC; hence, only male mice have been used and analyzed in this study [13]. White albino mice are internationally accepted model which could be extrapolated to human beings. Further, their ease of maintenance, handling, and their high reproduction rate make them particularly suitable models for human-oriented research. Their genome has been sequenced and many genes have human homologs.

The present investigation focused to elucidate the beneficial effect of natural plant-derived $\beta$-carboline alkaloid, harmalol, against HCC in the mice model to design a better therapeutic agent worldwide. Earlier, the aqueous and alcoholic extracts of Peganum harmala seeds having $\beta$ carboline alkaloid extracts have been reported to show potent antitumor and antiproliferative activity [14]. P. harmala extract caused a significant improvement in liver and kidney function in mice administered methotrexate drug [15]. However, our previous investigations on this naturally occurring indole derivative showed that it induced ROS-mediated, caspase 3- and p53-activated apoptosis against in vitro HepG2 cells [16]. It showed intercalative mode of binding, preferred hetero GC sequence specificity [17], and exhibited RNA binding ability [18]. But, most of the detailed therapeutic indications of harmalol are still a lacuna. Hence, this investigation primarily focused on several liver marker enzymes and gross morphological assessment of liver associated with several histological alterations that lead to HCC has been included in this study. Furthermore, the effective minimum dose of harmalol treatment is also included that finally put a conclusion through mRNA expression by RT-PCR and apoptotic marker proteins by western blot study in addition to the in vivo ROS generation analysis.

\section{Methods}

Chemicals and reagents

Harmalol and CT DNA were purchased from SigmaAldrich (St. Louis, MO, USA). The purity of the sample 
was confirmed as done earlier $[17,19]$. Their concentrations were determined using their molar extinction coefficient value of 19,000 and $6600 \mathrm{M}^{-1} \mathrm{~cm}^{-1}$, respectively, at 371 and $260 \mathrm{~nm}$ [17]. DEN ( $N$-nitrosodiethylamine) was also purchased from Sigma-Aldrich (St. Louis, MO, USA) and $\mathrm{CCl}_{4}$ was purchased from Merck, India. All chemical reagents for phosphate buffer Saline and 10\% neutral buffer formalin that were used were of analytical grade.

\section{UV-spectroscopic studies}

The absorbance spectral studies between DEN and CT DNA were measured on a Jasco V-630 double beam monochromator spectrophotometer (Jasco International Co. Ltd. Tokyo, Japan) of $1-\mathrm{cm}$ pathlength at $25 \pm 0.5^{\circ} \mathrm{C}$

\section{Animal care and experiment}

Male Swiss albino mice (Mus musculus) weighing 20$22 \mathrm{~g}$ (4-6 weeks old) were purchased from a registered breeder of animals. All mice were bred and maintained under constant conditions at a temperature of $24 \pm 1{ }^{\circ} \mathrm{C}$ and humidity of $55 \pm 5 \%$ with 12 -h light and 12-h dark cycles. Water and feed were accessible to the mice ad libitum [20]. Animal care (clean cage with sterilized bedding, food, drinking water) and all experimental protocols were performed according to the health criteria of laboratory animals and the study was conducted after obtaining Institutional Animal Ethical Committee clearance under the registration no. 892/GO/Re/S/01/ CPCSEA, dated 20 April 2014-28 April 2019, University of Kalyani. The animals were kept under quarantine for 1 week prior to the experiment. All experimental animals were procured from a registered breeder (address: Shri Sanjay Saha, Proprietor, Saha Enterprise, 386/2 Nilachal Birati, Kolkata 700051, W. Bengal) and they transported the animals in good health (certified by an appointed veterinarian) in the animal house. Animal cage size of $290 \times$ $220 \times 140 \mathrm{~mm}$, made of PVC, are generally used accommodating two animals per cage with proper labeling.

The dose for euthanasia was $30 \mathrm{mg} / \mathrm{kg}$ of Ketamine$\mathrm{HCl}$ and $3 \mathrm{mg} / \mathrm{kg}$ of Xylazine- $\mathrm{HCl}$, intraperitoneally (I.P.) given. Duration of effect was $\sim 30 \mathrm{~min}$.

Animal care and experimentation adheres to ARRIVE guidelines (Animal Research: Reporting of In Vivo Experiments)

\section{Experimental design}

The dose of both carcinogen and harmalol were selected as per the $\mathrm{LD}_{50}$ and acute toxicity of mice maintained under constant laboratory conditions [21]. The calculated $\mathrm{LD}_{50}$ of DEN, $\mathrm{CCl}_{4}$, and harmalol are $465 \mathrm{mg} / \mathrm{kg}, 3$ $\mathrm{ml} / \mathrm{kg}$, and $190 \mathrm{mg} / \mathrm{kg}$ body weight, respectively, through I.P. However, the acute toxicity of $\mathrm{DEN}, \mathrm{CCl}_{4}$, and harmalol are $310 \mathrm{mg} / \mathrm{kg}, 2.2 \mathrm{ml} / \mathrm{kg}$, and $120 \mathrm{mg} / \mathrm{kg}$ body weight, respectively.
Figure S1 represents a schematic illustration of in vivo experimental design of induction towards hepatocellular carcinoma and its treatment with harmalol. Experimental male mice were randomly divided into seven groups, each group consisting of five animals and their periodic induction with carcinogen and treatment with harmalol according to Table 1.

Group I: Controls received the vehicle of normal saline $(0.2 \mathrm{ml} / \mathrm{kg}$, B.W. I.P. $)$ and made sacrifice after 21 st week.

Group II: Received harmalol (10 mg/kg B.W., I.P. per week) for 9 weeks

Group III: Received DEN (24 mg/kg B.W. of I.P.) for first 12 weeks and received the vehicle of normal saline $(0.2 \mathrm{ml} / \mathrm{kg}$, B.W. I.P.) for last 9 weeks, and the total accumulation of DEN was $(288 \mathrm{mg} / \mathrm{kg}$ B.W of I.P.) for 12 weeks

Group IV: Received $\mathrm{CCl}_{4}(0.2 \mathrm{ml} / \mathrm{kg} \mathrm{B.W.})$ for the first 4 weeks (total accumulation of $0.8 \mathrm{ml} / \mathrm{kg}$, B.W of I.P)

Group V: Received DEN (24 mg/ $\mathrm{kg}$ B.W. of I.P.) for first 12 weeks (total accumulation was $288 \mathrm{mg} / \mathrm{kg}$, B.W.) and simultaneously administered $\mathrm{CCl}_{4}(0.2 \mathrm{ml} / \mathrm{kg} \mathrm{B.W}$. of I.P.) for 4 weeks (Total accumulation of $0.8 \mathrm{ml} / \mathrm{kg}$, B.W of I.P.) and received the vehicle of normal saline $(0.2 \mathrm{ml} / \mathrm{kg}$, B.W. of I.P.) for last 9 weeks

Group VI (pre-treated): Received aqueous solution of harmalol of $(10 \mathrm{mg} / \mathrm{kg}$ B.W of I.P.) for first 9 weeks followed by administration of $\mathrm{DEN}+\mathrm{CCl}_{4}$ up to the 21st week (dose vide supra)

Group VII (post-treated): Mice post-treated with harmalol $(10 \mathrm{mg} / \mathrm{kg}$ body weight $)$ for 9 weeks after the administration of DEN for 12 weeks (i.e., after administering DEN alone for 12 weeks, the mice were treated with harmalol along with DEN for another 9 weeks) and continued till the end of the experiment.

The carcasses of the sacrificed mice were disposed of by biomedical waste disposal method.

\section{Gross morphological assessment of liver}

The mice were weighed periodically and their body weights were recorded. The livers of the respective groups were removed, weighed, and examined for the presence of grossly visible lesions, and morphological changes were observed.

\section{Transmission electron microscopy}

Transmission electron microscopy (TEM) was performed using TECNAI 200KV TEM (Fei Electron Optics), $35 \mathrm{~mm}$ Photography System from All India Institute of Medical Science, N. Delhi. HepG2 cells were seeded in $100-\mathrm{mm}$ plates at a density of $2 \times 10^{8}$ cell in DMEM cell culture media for overnight and after adherence, cells were treated with harmalol of 7,14 , and $21 \mu \mathrm{M}$ concentrations (concentrations at $\mathrm{GI}_{25}, \mathrm{GI}_{50}$, and $\mathrm{GI}_{75}$, respectively) at $37^{\circ} \mathrm{C}$ for $48 \mathrm{~h}$. Cells were trypsinized and then the cultured materials were centrifuged 
Table 1 Different doses of carcinogen (DEN/CCl $\left./ \mathrm{DEN}+\mathrm{CCl}_{4}\right)$ and harmalol during 0-21 weeks of treatment in male Swiss albino mice (Mus musculus)

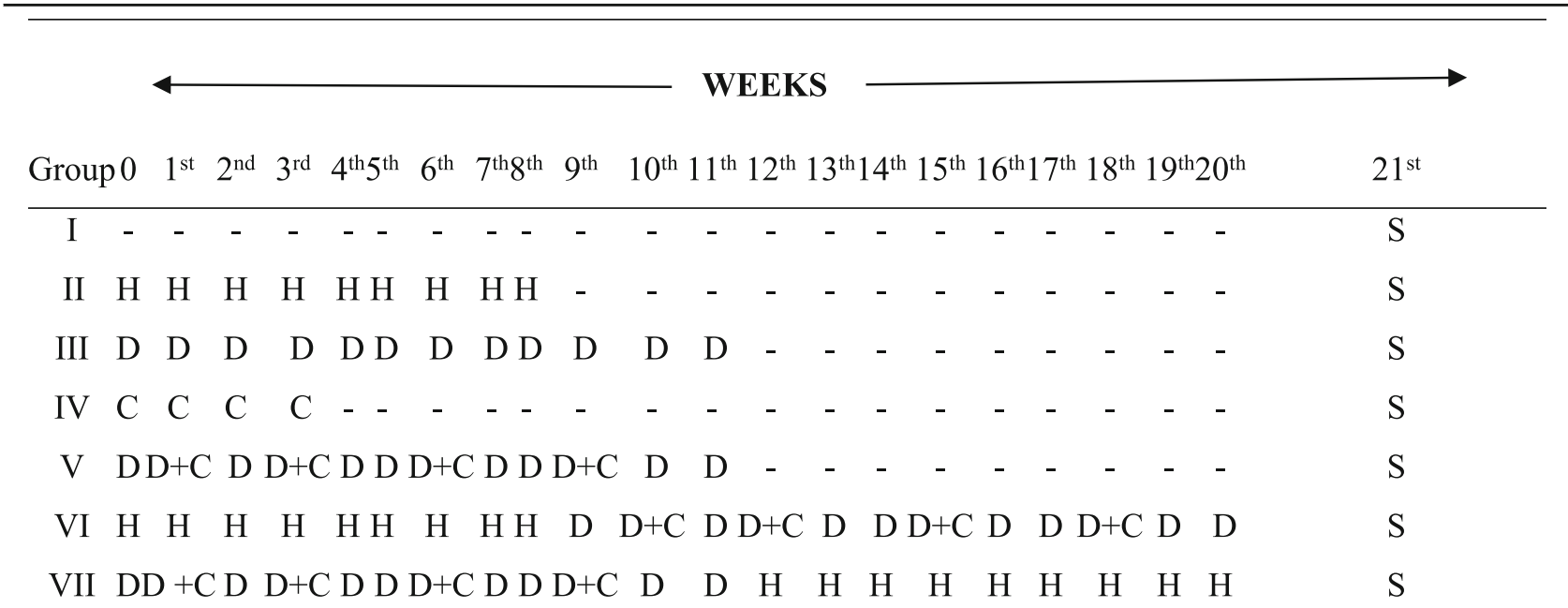

Here " $\mathrm{H}^{\prime}$, “D”, and "C" denote harmalol (10 mg/kg B.W. per week) for 9 weeks, DEN (24 mg/kg B.W. per week) for 12 weeks, and CCl $(0.2 \mathrm{ml} / \mathrm{kg}$ B.W. per week) for

4 weeks, respectively; "_" means continuously receive vehicle of normal saline $(0.2 \mathrm{ml} / \mathrm{kg}$, B.W. I.P. per week); and "S" stands for sacrifice

at $3000 \mathrm{rpm}$ for $4-5 \mathrm{~min}$ to discard the supernatant. The pellet was suspended in $0.1 \mathrm{M}$ phosphate buffer ( $\mathrm{pH} 7.4$ ), dispersed, and centrifuged again. The pellet was resuspended and fixed in a mixture of $2 \%$ paraformaldehyde and $2.5 \%$ glutaraldehyde in buffer for $3-4 \mathrm{~h}$ at $4{ }^{\circ} \mathrm{C}$, centrifuged for $10 \mathrm{~min}$ at $4{ }^{\circ} \mathrm{C}$ and the supernatant were discarded. The samples were finally prepared for observation.

\section{Assessment of liver function by enzyme assay}

Blood from seven different groups of mice was collected from the tail-vein after a specific time interval. Serum was obtained by centrifugation at $3000 \mathrm{rpm}$ for $10 \mathrm{~min}$ at $4{ }^{\circ} \mathrm{C}$. Biochemical parameters, i.e., ALP [22], lactate dehydrogenase (LDH) assay [23], total bilirubin, AST, and ALT [24] were analyzed according to the reported methods. The kits for ALP, LDH activity, total bilirubin, AST, and ALT were purchased from Span Diagnostic, India.

\section{Determination of ALP}

The response of the liver to any form of damage and obstruction is to synthesize more ALP [25-27]. Changes in absorbance are measured kinetically at $405 \mathrm{~nm}$ due to yellow color formation and are proportional to ALP activity in the sample [25, 26, 28].

ALP activity $(\mathrm{IU} / \mathrm{L})=\Delta A /$ minute $\times$ Kinetic factor, where $\Delta A /$ minute $=$ change in absorbance per minute and Kinetic factor $(K)=2712$

\section{Determination of activity of LDH}

Increased levels of LDH were also found in case of hepatic diseases [23]. Serum sample of each group (untreated and treated groups) was mixed well. The initial absorbance $A_{0}$ was measured spectrophotometrically at $340 \mathrm{~nm}$ and reading was taken repeatedly after every 1 , 2 , and $3 \mathrm{~min}$. The mean absorbance change per minute $(\triangle \mathrm{A} / \mathrm{min})$ was calculated as follows:

$\mathrm{LDH}$ activity in $\mathrm{U} / \mathrm{L}$ for $25^{\circ} \mathrm{C} / 30^{\circ} \mathrm{C}=\Delta \mathrm{A} / \mathrm{min} \times 3333$ and for $37^{\circ} \mathrm{C}=\Delta \mathrm{A} / \mathrm{min} \times 8095$

\section{Determination of total bilirubin}

Red-purple-colored azobilirubin is measured spectrophotometrically at $540 \mathrm{~nm}$ and it is proportional to the concentration of the appropriate fraction of bilirubin. The concentration of total bilirubin was calculated in $\mathrm{mg} / 100 \mathrm{ml}$.

\section{Detection of activity of AST}

Serum AST level is elevated in case of liver diseases associated with hepatic necrosis. Serum samples of each group were mixed with working AST reagent and absorbances were taken at $340 \mathrm{~nm}$.

AST activity $(\mathrm{IU} / \mathrm{L})=\Delta \mathrm{A} /$ minute

$$
\begin{aligned}
\times & \text { Kinetic factor, where } \Delta \mathrm{A} / \text { minute } \\
= & \text { change in absorbance per } \\
& \text { minute and Kinetic factor }(K)=1768
\end{aligned}
$$

\section{Detection of activity of ALT}

Serum ALT level is also elevated in case of liver diseases associated with hepatic necrosis. ALT is a more liverspecific enzyme. Serum sample of each group was mixed well with working AST reagent and absorbances were taken and reading was taken at $340 \mathrm{~nm}$. 


\section{Detection of hepatocarcinoma indicators}

The activity of hepatic DNA in the liver tissue was assayed by methods of Giles and Myres [29] and Burton [30]. The hepatic RNA level was estimated by methods of Almog and Shirey [31] and Blobel and Potter [32]. Hepatic protein was estimated by the method of Lowry et al. [33]. The activity of serum alpha-fetoprotein (AFP) level was also assayed.

\section{Histological studies}

Mice from each group were taken and sacrificed after a specific time interval. After draining the blood, liver samples were excised, washed with normal saline $(0.9 \% \mathrm{NaCl})$, and processed separately for histopathological observation according to Alarami [34]. The hematoxylin and eosin (H\&E) stained sections were examined under a light microscope, Leitz (Biomed), and histopathological changes were captured by a Nikon Camera, EOS700D, 18-55 lens.

\section{RT-PCR and western blot analysis}

Equal amounts of total RNA, extracted with TRIZOL Reagent (Himedia, Mumbai, India), were reverse transcribed and then subjected to PCR with enzymes and reagents of the reverse transcription system using the technique of PCR system as reported earlier by Sarkar et al. [16]. Sequences of primers used in the study are given in Table S1. G3PDH was used as loading control. PCR kit (Taq Mix Kit), RT-PCR kit, and RNasin were purchased from SRL, Pvt. Ltd. Oligonucleotide primers for caspase3, p53, and G3PDH were purchased from Xcelris Labs Limited.

Total protein content from the liver of the control, harmalol post-treated, and $\mathrm{DEN}$ - and $\mathrm{CCl}_{4}$-induced group of mice were extracted and western blot analysis was performed as described by Lee [35]. Tubulin was used as loading control. Anti-active caspase 3 monoclonal primary antibody $(17 \mathrm{Kd}$, anti-mouse, Santa Cruz Biotechnology), tubulin, and anti p53 monoclonal primary antibody (anti-mouse) were purchased from Santa Cruz Biotechnology, and anti-mouse secondary antibody was purchased from Sigma-Aldrich.

\section{In vivo ROS generation and its quantification by FACS}

The liver from different groups was collected and a freshly prepared solution of $0.5 \mathrm{mM}$ EDTA and collagenase type I $0.8 \mathrm{mg} / \mathrm{ml}$ in DMEM media was added to the section of the liver sac to release the hepatocytes according to Severgnini et al. [36]. The levels of intracellular ROS were assessed by flow cytometry after incubating with DCFHDA $(20 \mathrm{mM})$ (dichloro fluorescence diacetate) for $30 \mathrm{~min}$ at $37^{\circ} \mathrm{C}$.

\section{Statistical analysis}

The data obtained were calculated by SPSS 17.0. The values were expressed as mean \pm SEM. Statistical analysis was performed by one-way analysis of variance (ANOVA). Values of $p<0.05$ were considered significant.

\section{Results}

UV-vis spectral changes

DEN (diethylnitrosamine) is a potent hepatocarcinogenic nitrosamine compound, which is present in several sources. It is the nitrosamine that has the carcinogenic effect [37]. Endogenous nitrosamines can be formed in a similar way from their precursors, nitrates, and nitrites. The binding between DEN and CT DNA was studied by UV-vis absorption titration (Fig. 1). The characteristic UV-vis spectrum of DEN exhibited maxima at $338 \mathrm{~nm}$ in the range of $300-410 \mathrm{~nm}$. On titration with CT DNA of varied concentration and DEN of fixed concentration $(15 \mu \mathrm{M})$, the spectra exhibited a characteristic hypochromic effect of $18 \%$ and a bathochromic shift of $4 \mathrm{~nm}$ until saturation was reached at nucleotide phosphate/DEN molar ratio (P/D) 4.0. The characteristic hypochromic effect and bathochromic shift indicated a strong intermolecular interaction. But throughout the binding, no isosbestic point was observed that signifies that the interaction was not equilibrium based non-covalent binding.

In vitro cytotoxicity studies of harmalol in $\mathrm{HepG}_{2}$ cell line Apart from the binding study, the biological importance was further highlighted by in vitro cytotoxic assays to emphasize the apoptotic induction ability of harmalol in liver cancer cell line $\mathrm{HepG}_{2}$. Previously Sarkar et al. [16] had already revealed that harmalol showed cytotoxicity in different human cancer cell lines and out of all, $\mathrm{HepG}_{2}$ cell line showed maximum cytotoxicity with a minimum $\mathrm{IC}_{50}$ value of $14.2 \mu \mathrm{M}$. Figure $2 \mathrm{a}$ depicts the phase-contrast microscopic images of the control and treated $\mathrm{HepG}_{2}$ cells with different concentrations of harmalol. Furthermore, ultra-morphological study by TEM (Fig. 2b), which is considered the customary to confirm apoptosis, further discovered some early and late 


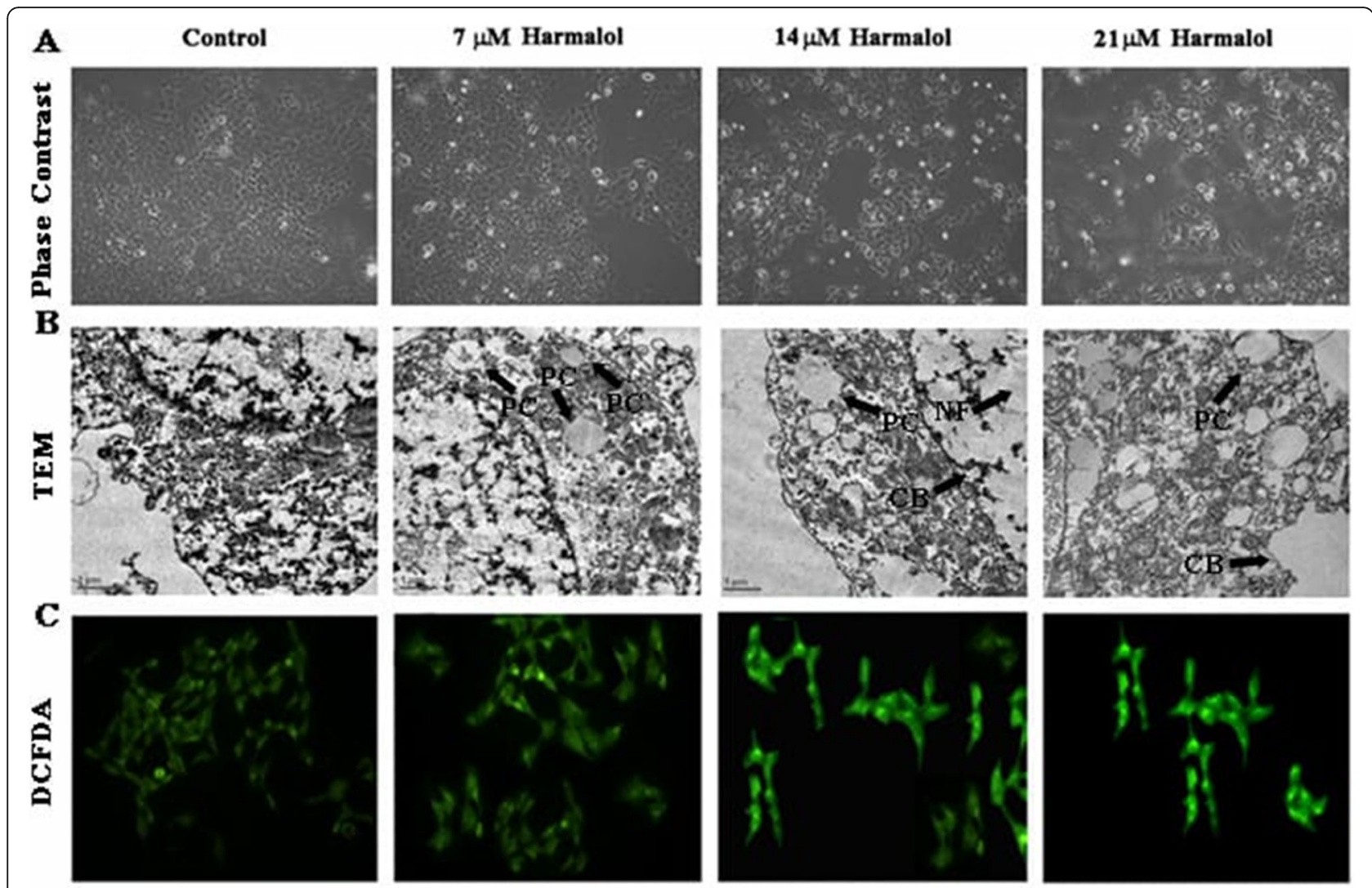

PC- Phagolysosomal complex; CB-Cytoplasmic Blebbing; NF-Nucleolous fragmentation

Fig. 2 a Phase-contrast microscopic images, $\mathbf{b}$ changes of membranes of HepG2 cells in TEM, and $\mathbf{c}$ ROS generation study by DCFH-DA under a fluorescent microscope $(\times 200)$. Abbreviations are represented below the images

apoptotic features like nucleolus fragmentation, cytoplasmic blebbing, and formation of phagolysomal complex. ROS generation study was also performed (Fig. 2c) by adding DCFH-DA $(25 \mu \mathrm{M})$ in control and harmaloltreated $\mathrm{HepG}_{2}$ cells (at $\mathrm{IC}_{50}$ concentration) for $24 \mathrm{~h}$ under a fluorescent microscope.
Light microscopic studies

Light microscopic images of the intact liver are shown in Fig. 3a-c. Control (Group I) mice showed normal as a reddish-brown wedge-shaped architecture of the liver (Fig. 3a). Macroscopically the liver extracted from group $\mathrm{V}$ showed several lesions as multifocal nodular hyperplasia
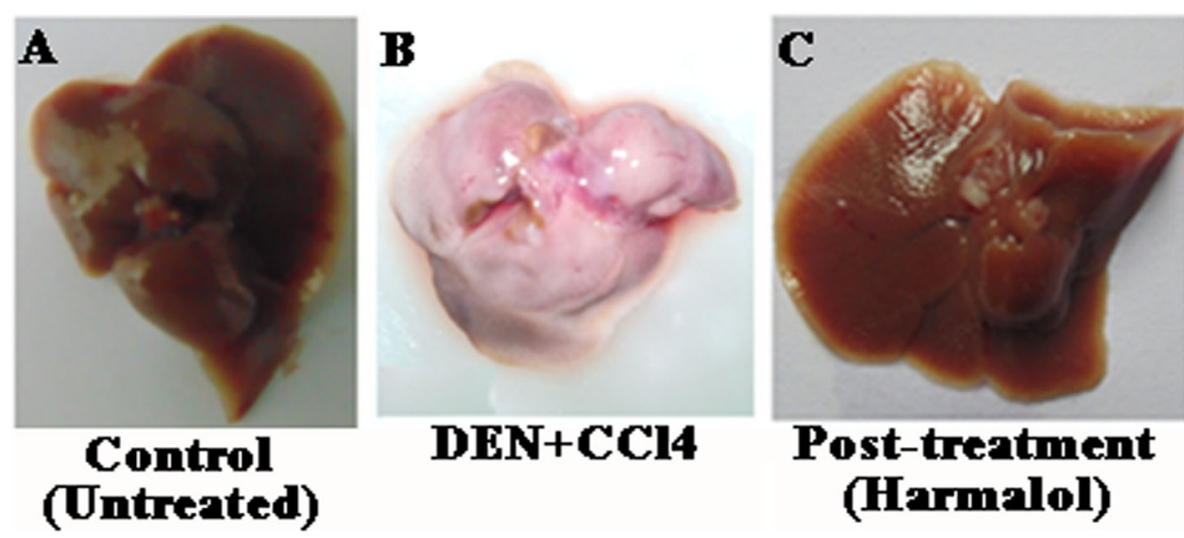

Fig. 3 Photographic images of gross liver in different groups of experimental mice. a The liver of control mice. $\mathbf{b}$ After the 21 st week of DEN+ $\mathrm{CCl}_{4}$-injected mice (group V). c Harmalol post-treated mice 
and the entire structure was complete whitish-pink in color with blood drained structure. Multifocal and infiltrating types of growth patterns were observed in $\mathrm{DEN}+\mathrm{CCl}_{4}$ (Group V)-injected mice liver (Fig. 3b). While harmalol post-treated (group VII) mice liver was also found in nearnormal architecture, reddish-brown color, and normal shape and size (Fig. 3c). The results further showed the disappearance of gray-white nodular patches from the surface of the liver after 9 weeks of post-treatment (total accumulation of $90 \mathrm{mg} / \mathrm{kg}$ of harmalol). Light microscopic examinations of the liver of the remaining experimental groups have been shown in Figure S2.

\section{General observation and body and liver weight}

The final body weight and absolute liver weights were also collated in Table 2. All groups were subjected to dying sacrifice after 21 weeks. Final body weights were remarkably decreased in group III with a body weight of $17.3 \pm 3.2 \mathrm{~g}$ and group $\mathrm{V}$ with $13.6 \pm 1.6 \mathrm{~g}$ body weight as compared with harmalol-treated and control group (division of various groups in details have been shown in the "Experimental design" section). But, the absolute liver weights in the mentioned groups (i.e., groups III, $\mathrm{IV}$, and V) were significantly decreased, though the decrease was more pronounced among group $\mathrm{V}$ and it was $0.96 \pm 0.9 \mathrm{~g}$ (Fig. 3b). Decreased liver weight in these groups was attributed to decreased body weight.

\section{Assay of liver marker enzymes}

After the study of apparent body and liver weight, blood samples from all seven groups were collected and serum level of alkaline phosphatase (ALP), lactate dehydrogenase (LDH), bilirubin, aspartate aminotransferase (AST), and alanine aminotransferase (ALT) were estimated. Data obtained from the biochemical assays were analyzed and presented in Table 3 which showed the mean serum levels of ALP, LDH, bilirubin, AST, and ALT in all healthy or controlled, harmalol control, different groups of carcinogens induced, and harmalol pre- and post-treated groups of mice, respectively. The parameters were further represented as a bar graph (Fig. 4a-e). The values of all these enzymes were significantly higher $(p<0.05)$ in $\mathrm{DEN}+\mathrm{CCl}_{4}$, i.e., group $\mathrm{V}$ treated group with $650.85 \pm 20 \mathrm{IU} / \mathrm{L}, 1801.1 \pm 60 \mathrm{IU} / \mathrm{L}, 2.36 \pm 0.098 \mathrm{mg} / \mathrm{dL}$, $495.5 \pm 18 \mathrm{IU} / \mathrm{L}$, and $477.36 \pm 15 \mathrm{IU} / \mathrm{L}$ in ALP, LDH, bilirubin, AST, and ALT, respectively. It showed the highest percentage of marker liver enzymes above the normal level.

Furthermore, there was a drop in the hemoglobin level in the hepatocarcinoma-affected mice. Normal hemoglobin was found to be $9.7 \mathrm{mmol} / \mathrm{L}$, whereas in the diseased mice it was $8.4 \mathrm{mmol} / \mathrm{L}$, reflecting acute anemia. In the postharmalol-treated group, it was reported to be $9.3 \mathrm{mmol} / \mathrm{L}$.

\section{Alpha-fetoprotein as hepatocarcinoma indicator}

The changes in the level of hepatic DNA, RNA, and normal serum protein level in the liver tissue of control and experimental groups were studied and the quantitative values are presented in Table 4 and Fig. 5a. Mice administered with $\mathrm{DEN} / \mathrm{CCl}_{4}$ showed a significant increase in DNA and RNA levels than the control and post-treated groups while the normal serum protein level was significantly low in the group of mice administered with DEN/ $\mathrm{CCl}_{4}$ compared to control and post-treated groups. But, the activity of serum alpha-fetoprotein (AFP) level was significantly increased in $\mathrm{DEN} / \mathrm{CCl}_{4}$ when compared to

Table 2 Body and liver weight in Swiss albino mice

\begin{tabular}{|c|c|c|c|c|c|c|c|}
\hline Group no. & Treatment & No. of Mice & Final weight (g) & 1st week & 7th week & 14th week & 21st week \\
\hline \multirow[t]{2}{*}{ I } & \multirow[t]{2}{*}{ Control (untreated) } & \multirow[t]{2}{*}{5} & Body & $25.3 \pm 2.1$ & $25.7 \pm 2.3$ & $26.1 \pm 2.2$ & $26.3 \pm 2.1$ \\
\hline & & & Liver & $1.69 \pm 0.13$ & $1.68 \pm 0.12$ & $1.69 \pm 0.14$ & $1.69 \pm 0.13$ \\
\hline \multirow[t]{2}{*}{$\|$} & \multirow[t]{2}{*}{ Harmalol treated } & \multirow[t]{2}{*}{5} & Body & $25.6 \pm 2.3$ & $26.2 \pm 2.1$ & $26.8 \pm 2.4$ & $25.1 \pm 2.3$ \\
\hline & & & Liver & $1.66 \pm 0.11$ & $1.57 \pm 0.12$ & $1.58 \pm 0.14$ & $1.55 \pm 0.13$ \\
\hline \multirow[t]{2}{*}{ III } & \multirow[t]{2}{*}{$\mathrm{CCl}_{4}$ treated } & \multirow[t]{2}{*}{5} & Body & $25.2 \pm 3.1$ & $22.6 \pm 3.1$ & $19.1 \pm 3.4$ & $17.3 \pm 3.2^{*}$ \\
\hline & & & Liver & $1.62 \pm 0.28$ & $1.56 \pm 0.22$ & $1.43 \pm 0.32$ & $1.35 \pm 0.36^{*}$ \\
\hline \multirow[t]{2}{*}{ IV } & \multirow[t]{2}{*}{ DEN treated } & \multirow[t]{2}{*}{5} & Body & $24.5 \pm 1.9$ & $20.2 \pm 1.5$ & $17.5 \pm 1.1$ & $15.6 \pm 1.2^{*}$ \\
\hline & & & Liver & $1.50 \pm 0.27$ & $1.41 \pm 0.25$ & $1.33 \pm 0.14^{*}$ & $1.19 \pm 0.11^{*}$ \\
\hline \multirow[t]{2}{*}{ V } & \multirow[t]{2}{*}{$\mathrm{DEN}+\mathrm{CCl}_{4}$ treated } & \multirow[t]{2}{*}{5} & Body & $20.2 \pm 2.9$ & $18.3 \pm 3.6$ & $15.4 \pm 2.7$ & $13.6 \pm 1.6^{*}$ \\
\hline & & & Liver & $1.45 \pm 0.16$ & $1.32 \pm 0.19$ & $1.23 \pm 0.33^{*}$ & $0.96 \pm 0.9^{*}$ \\
\hline \multirow[t]{2}{*}{$\mathrm{Vl}$} & \multirow[t]{2}{*}{ Pre-treatment with harmalol } & \multirow[t]{2}{*}{5} & Body & $25.5 \pm 2.5$ & $25.3 \pm 2.8$ & $24.6 \pm 2.8$ & $24.1 \pm 2.3^{*}$ \\
\hline & & & Liver & $1.59 \pm 0.17$ & $1.57 \pm 0.22$ & $1.56 \pm 0.27$ & $1.49 \pm 0.23^{*}$ \\
\hline \multirow[t]{2}{*}{ VII } & \multirow[t]{2}{*}{ Post-treatment with harmalol } & \multirow[t]{2}{*}{5} & Body & $20.6 \pm 2.4$ & $18.2 \pm 2.6^{*}$ & $22.8 \pm 2.2^{*}$ & $24.9 \pm 1.8$ \\
\hline & & & Liver & $1.47 \pm 0.24$ & $1.33 \pm 0.29^{*}$ & $1.46 \pm 0.25^{*}$ & $1.66 \pm 0.23$ \\
\hline
\end{tabular}

Mice were sampled 21 weeks after the initiation of treatment, and values represented means \pm SE

*Significantly different from the control groups $(p<0.05)$ 


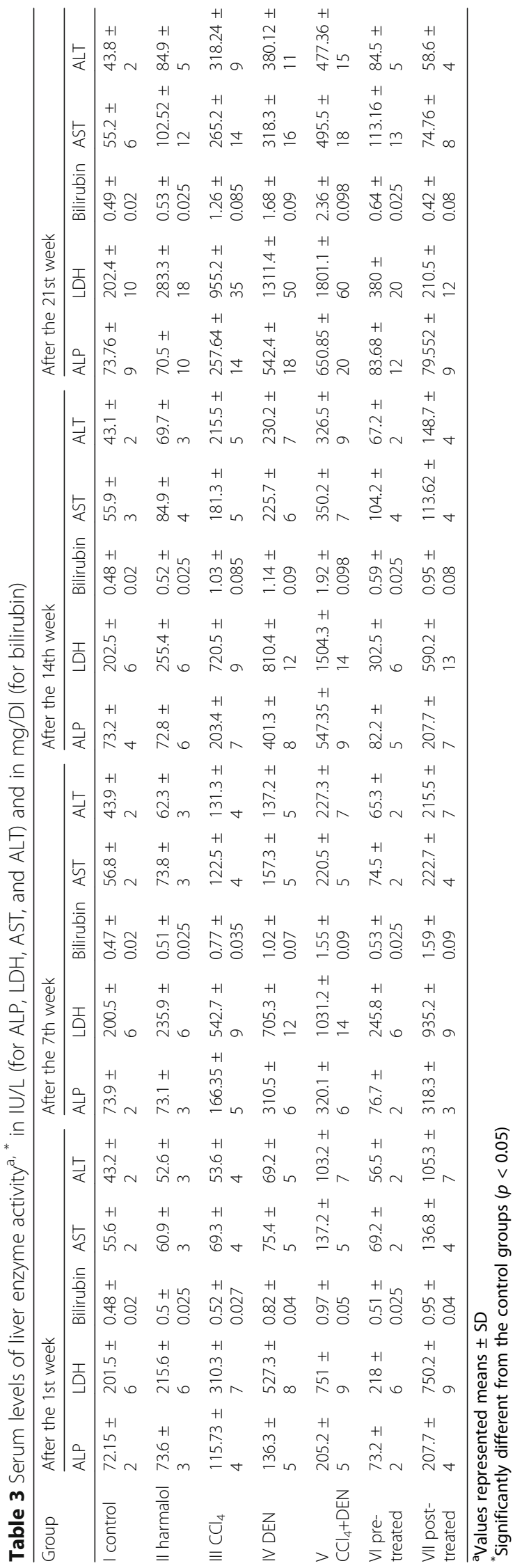



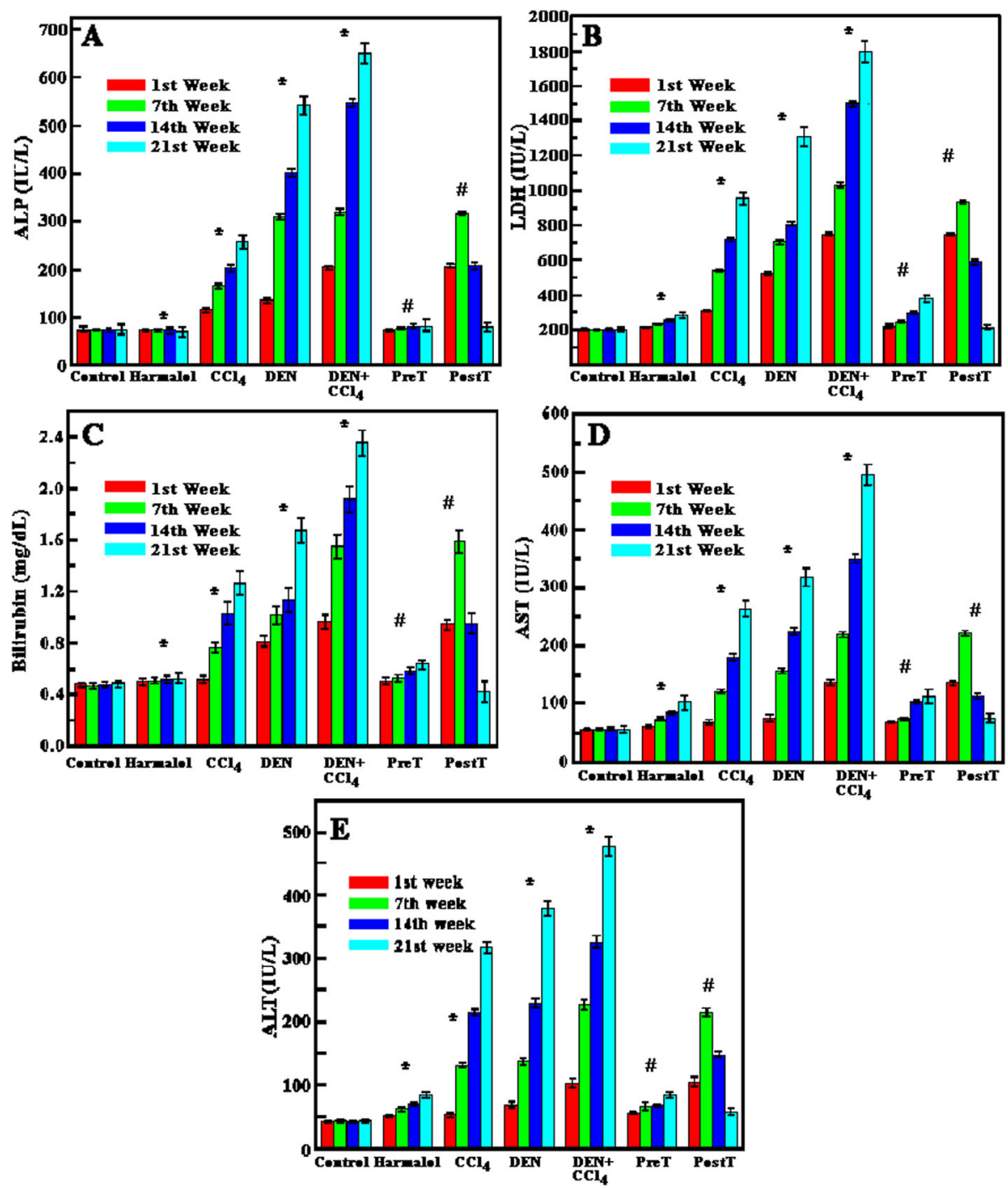

Fig. 4 Bar graph representation showing the effect of carcinogen (DEN+ $\left.C C_{4}\right)$ and harmalol treatment on experimental mice by measuring the serum level of liver functional enzymes. a ALP, b LDH, c bilirubin, $\mathbf{d}$ AST, and e ALT after different time period. Control, harmalol-treated (total 80 mg/kg B.W.), $C C_{4}$-treated, DEN-treated, DEN+CCl- -treated, pre-treatment (Pre-T) with harmalol (total $80 \mathrm{mg} / \mathrm{kg}$ B.W.) and post-treatment (Post-T) with harmalol (total $80 \mathrm{mg} / \mathrm{kg}$ B.W.) are presented here. Data are presented as mean $\pm \mathrm{SE}$, ${ }^{*} P<0.05$ compared with the control group; ${ }^{\#} P<0.05$ compared with the $\mathrm{DEN}+\mathrm{CCl}_{4}$-treated group

Table 4 Quantitative values of different hepatic marker viz. DNA, RNA, protein, and AFP levels ${ }^{a,}{ }^{*}$ after the 21 st week of exposure of harmalol and carcinogens

\begin{tabular}{|c|c|c|c|c|}
\hline Groups & DNA & RNA & Normal serum protein & AFP level in serum \\
\hline I & $0.7 \pm 0.1$ & $0.9 \pm 0.08$ & $13.5 \pm 0.1$ & $0.30 \pm 0.02$ \\
\hline$\|$ & $0.75 \pm 0.2$ & $0.92 \pm 0.009$ & $12.9 \pm 0.2$ & $0.34 \pm 0.03$ \\
\hline III & $2.1 \pm 0.6$ & $2.6 \pm 0.4$ & $8.4 \pm 0.5$ & $0.80 \pm 0.05$ \\
\hline IV & $1.9 \pm 0.4$ & $2.2 \pm 0.3$ & $9.2 \pm 0.5$ & $0.79 \pm 0.04$ \\
\hline V & $2.6 \pm 0.7$ & $2.8 \pm 0.6$ & $7.6 \pm 0.8$ & $0.83 \pm 0.07$ \\
\hline $\mathrm{Vl}$ & $1.6 \pm 0.4$ & $1.8 \pm 0.2$ & $10.2 \pm 0.3$ & $0.55 \pm 0.03$ \\
\hline VII & $1.2 \pm 0.3$ & $1.6 \pm 0.1$ & $11.8 \pm 0.2$ & $0.42 \pm 0.02$ \\
\hline
\end{tabular}

aalues represented means \pm SD

* Significantly different from the control groups $(p<0.05)$ 

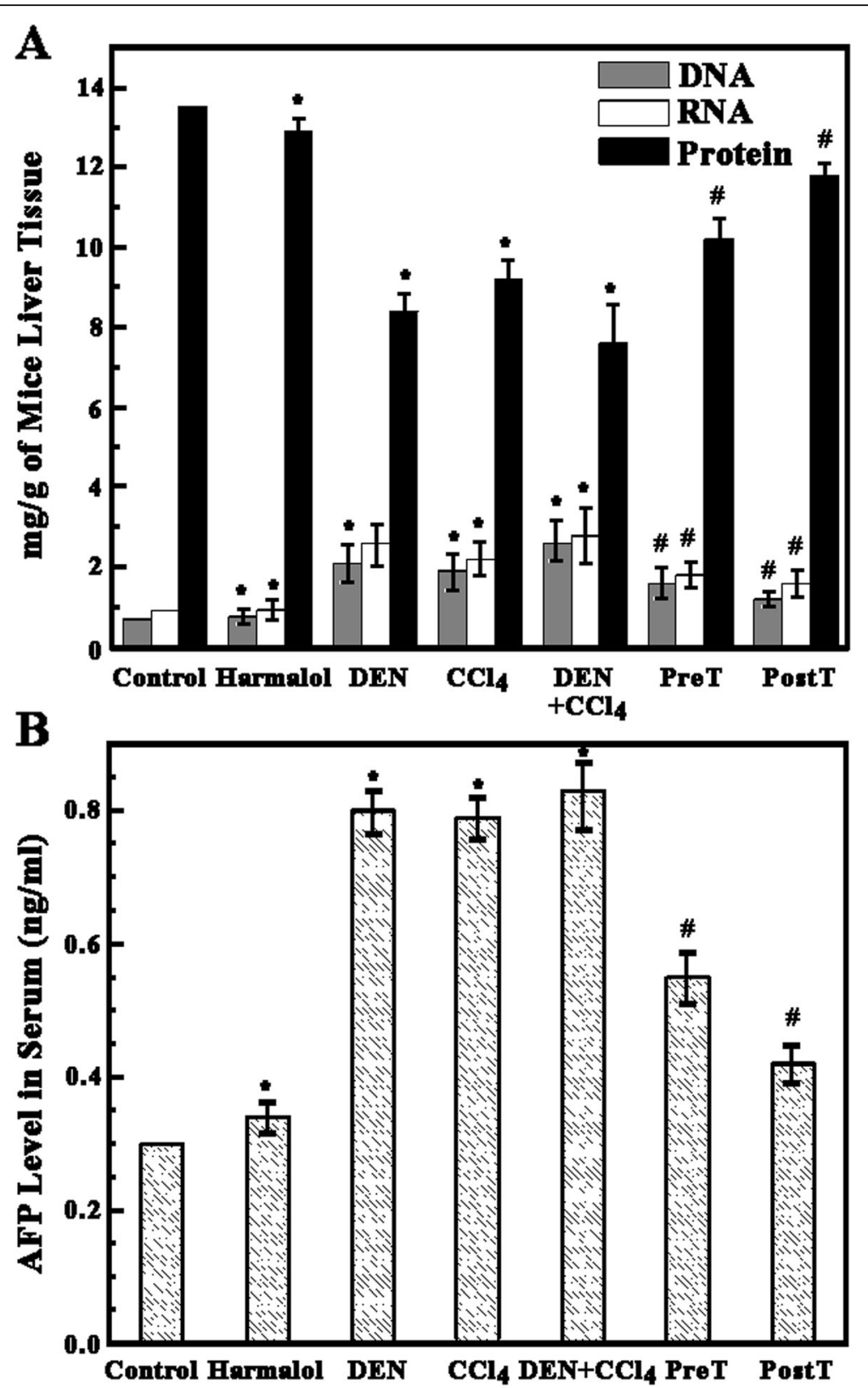

Fig. 5 a Bar graph representation showing the estimation of hepatic DNA, RNA, and normal serum protein level in seven different experimental groups. b Bar graph representation of the alpha-fetoprotein level in serum of seven different experimental groups. Data are presented as mean \pm $\mathrm{SE},{ }^{*} P<0.001$ compared with the control group; ${ }^{\# P} P 0.001$ compared with the $\mathrm{DEN}+\mathrm{CCl}_{4}$-treated group

the normal group (Fig. 5b). A significant reduction in serum AFP level was observed in the treatment group (harmalol post-treated) when compared with $\mathrm{DEN} / \mathrm{CCl}_{4}$ group.

\section{Histological study}

Apart from the above study, a histological study was performed under light microscope using hematoxylin and eosin stain. Histology signifies the microscopic examination of tissue in order to study the manifestations of the specific disease. Specifically, in clinical medicine, histology, along with its pathological outcome, refers to the examination of a biopsy or surgical specimen, after the specimen has been processed and histological sections have been placed onto glass slides. In the presence of combined carcinogen, $\mathrm{DEN}+\mathrm{CCl}_{4}$ several characteristics of liver necrosis and $\mathrm{HCC}$ were found in experimental system after 12 weeks of injection and were presented in Fig. 6 elaborately. Toxic chemicals like several nitrosamine compounds, used as common food additives, could 

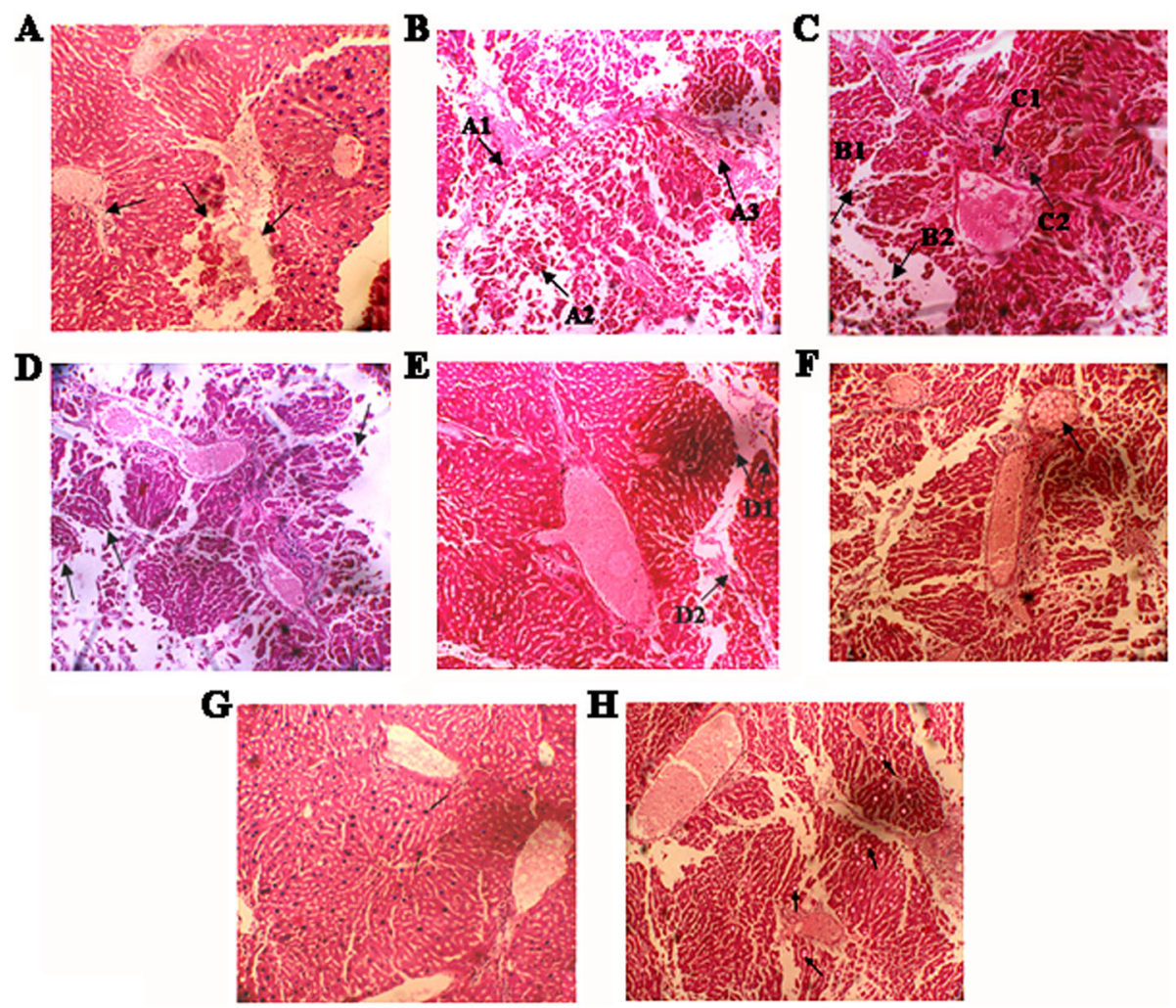

Fig. 6 Hematoxylin and eosin (H\&E) stained liver sections of DEN $+C_{C C l}$-induced mice (group V), a Centrilobular necrosis. b Fibrolamellar carcinoma liver where (A1) oncocytes, (A2) cord patterns, and nest formation which were separated by bands of (A3) fibrous stroma. c Peripheral/ periportal necrosis shown by (B1) and (B2), and (C1) and (C2) (pyknotic condition in the nuclei of hepatic cells). $\mathbf{d}$ Trabecular or sinusoidal patterns which are made up of 2-8-cell-wide layers of tumor cells separated by vascular spaces or sinusoids which are lined by endothelium, $\mathbf{e}$ (D1) and (D2) Different changes in liver tissues like nodule formation and fibrosis or cirrhosis, respectively. $\mathbf{f}$ Large eosinophilic AHF. $\mathbf{g}$ Small basophilic AHF. $\mathbf{h}$ Vacuolated cell AHF. H\&E stained liver sections are photographed at $\times 100$ magnification

induce HCC and could cause zonal necrosis of the liver $[38,39]$. Here, $\mathrm{DEN}+\mathrm{CCl}_{4}$ induced two types of zonal necrosis. Figure 6a shows centrilobular necrosis involving necrosis in hepatocytes around the central vein, while Fig. 6b shows fibrolamellar carcinoma where oncocytes formed cords (A1) and nests (A2) which were separated by bands of fibrous stroma (A3). Figure 6c (B1, B2) showed peripheral or periportal necrosis involving necrosis in parenchyma closest to the arterial and portal blood supply while $(\mathrm{C} 1)$ and (C2) showed pyknotic condition in the nuclei of hepatic cells. Figure $6 \mathrm{~d}$ portrayed trabecular or sinusoidal patterns which were actually made up of 2-8-cell-wide layers of tumor cells separated by vascular spaces or sinusoids which are lined by the endothelium layer. Figure 6e (D1, D2) represents different changes in liver tissues like nodule formation and fibrosis or cirrhosis, respectively. Furthermore, in DEN+ $\mathrm{CCl}_{4}$-induced mice, several AHF (altered hepatocellular foci) were also observed and represented in the figures below. Among them, large eosinophilic AHF (Fig. 6f), small basophilic AHF (Fig. 6g), and vacuolated cell AHF (Fig. 6h), in which hepatocellular cytoplasm was found to be vacuolated, have been highlighted.
Figure 7 further summarized the results of the histological examinations of untreated, carcinogen-induced, harmalol pre- and post-treated mice liver elaborately. Several characteristics of HCC and necrosis described above were identified in the carcinogen-induced group and $\mathrm{HCC}$ was found to be developed in the $\mathrm{DEN}+\mathrm{CCl}_{4}$ treated group (group V) after the 12th week. HCC was identified in the $\mathrm{CCl}_{4}$-treated group (group IV) also. In all DEN-treated groups (group III), large eosinophilic and small basophilic AHF was identified. AHF condition increased in a dose-dependent manner and was statistically significant as compared with harmalol-treated and controlled values. Eosinophilic AHF was positively correlated to dose, but only those identified in group $\mathrm{V}$ were statistically significant. $\mathrm{DEN}+\mathrm{CCl}_{4}$ treatment led to a severe pyknotic condition of hepatic cells nuclei, vesiculation in the cytoplasm of the cells, sign of damage in the wall of central veins, hemorrhage, necrotic foci, degeneration, and hypertrophy in some of the hepatic cells. While the DEN-treated group showed a widening of some of the hepatic sinusoids, histology of $\mathrm{CCl}_{4}$-treated groups showed different changes in liver tissues like 


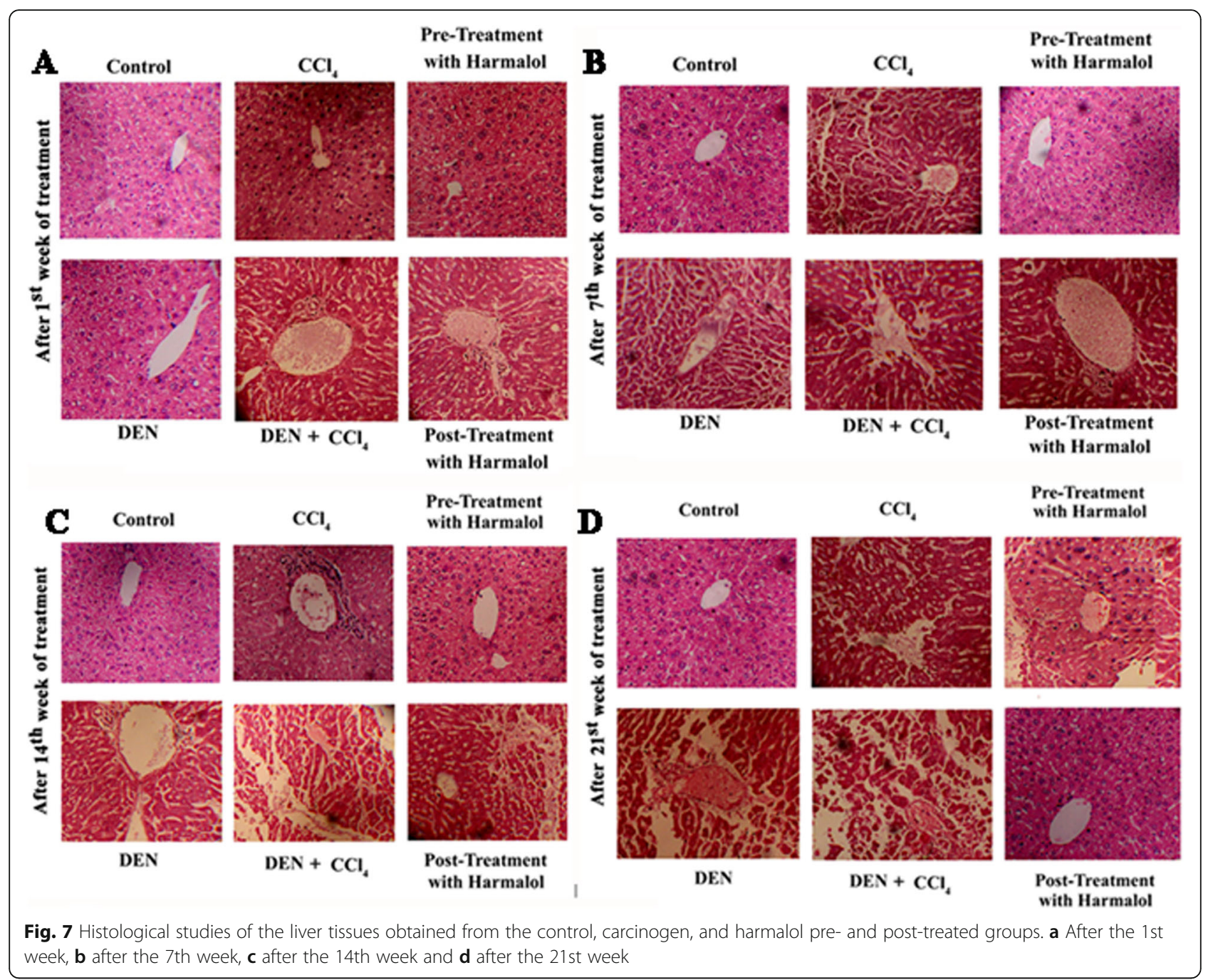

fibrosis (cirrhosis) and mononuclear polymorphic infiltration besides widening in some of the hepatic sinusoids, pyknotic, and vesiculation of hepatic cells. Thus, it can be summarized from the histopathological examination of mice in group III (DEN-treated mice) and group IV $\left(\mathrm{CCl}_{4}\right.$ treated mice) that histopathological deformities were far more prominent in group $\mathrm{V}$, i.e., $\mathrm{DEN}+\mathrm{CCl}_{4}$ treated group. While control group animals revealed normal architecture and animals pre-treated and posttreated with harmalol $(90 \mathrm{mg} / \mathrm{kg}$ B.W.) showed fewer neoplastic cells with the near-normal architecture of a very compact hexagonal or pyramidal structure with a very prominent central vein.

\section{Effect of harmalol on p53 and caspase 3 expressions}

Hepatoprotective action of harmalol was further confirmed by RT-PCR data revealing that unlike in the control group of mice, harmalol post-treatment resulted in activation of caspase 3 and increased expression of p53 (Fig. 8a). The expression of caspase-3, p53, and cytochrome $\mathrm{C}$ that favored apoptosis were up-regulated in a harmalol post-treated group (Fig. 8b). Figure 8b further exhibited the cleaved form of caspase-3, i.e., 17/19 kd. Together, the present results showed that harmalol induces apoptosis by potentially targeting the cleavage of procaspase- $3(34 \mathrm{kd})$ into active enzyme and both forms of caspase- 3 expression by western blot analysis, which are given with its quantitative presentation. Quantification of each marker is been represented by bar graphs. Evidence suggested that the p53 tumor suppressor gene is involved in cell cycle regulation, DNA repair, and programmed cell death, and it further led to caspase activation $[40,41]$.

\section{In vivo ROS detection}

The result was further complemented with in vivo ROSdependent cytotoxicity. ROS generation, induced by various anti-cancer agents [42-44], plays a key role in apoptosis. ROS levels were found to be elevated in the harmalol post-treated group. The mean fluorescent intensity changed (Table 5) from $21.3 \pm 0.9$ (control) to 


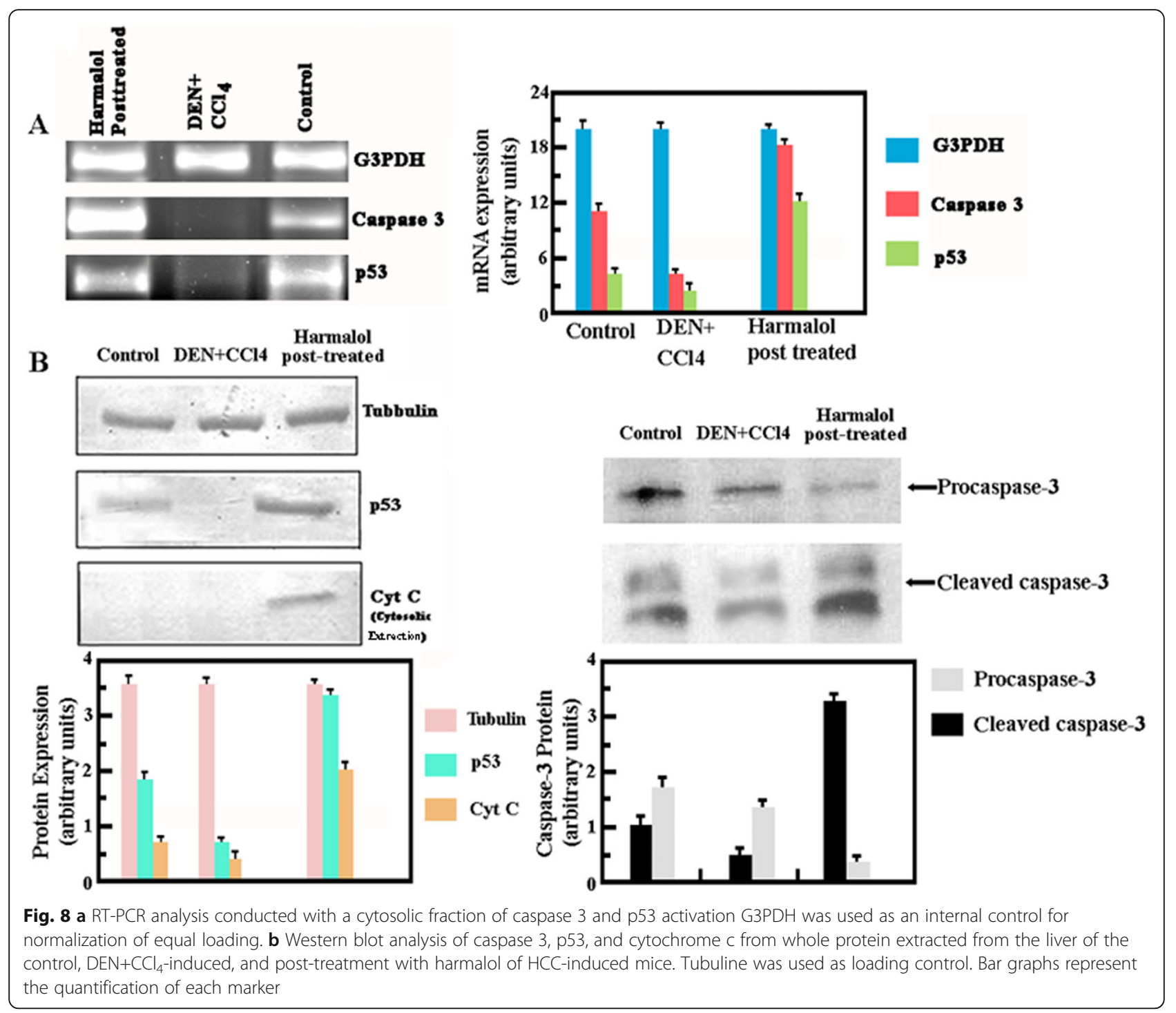

$28.6 \pm 0.8,71.4 \pm 0.8$, and $85.4 \pm 0.7$ in harmalol posttreated, DEN, and $\mathrm{DEN}+\mathrm{CCl}_{4}$-induced group, respectively (Fig. 9). ROS intensity increased nearly 4-folds relative to the control.

\section{Discussion}

Ability to induce apoptosis in cancer cells is an established hallmark feature of any drug with a good anti-

Table 5 Comparison between quantitative assay of ROS generation induced by harmine by DCFH-DA in HeLa cell lines through Flow cytometric analysis

\begin{tabular}{llll}
\hline Percent ROS ${ }^{\mathrm{a}, \mathrm{b},{ }^{*}}$ & & \\
\hline Control & Harmalol post-treated & DEN & DEN $+\mathrm{CCl}_{4}$ \\
\hline $21.3 \pm 0.9$ & $28.6 \pm 0.8$ & $71.4 \pm 0.8$ & $85.4 \pm 0.7$ \\
\hline
\end{tabular}

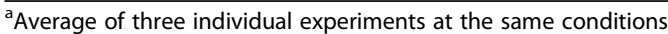

b values represented means $\pm S D$

*Significantly different from the control groups $(p<0.05)$ cancer potential [45]. Hence, the study highlighted the apoptotic induction ability of harmalol in an in vivo model to quantify the efficacy of the drug molecule inhibiting carcinogens inducing hepatocellular carcinoma (HCC). In vivo study was performed in seven groups of male Swiss albino mice administered with both DEN and $\mathrm{CCl}_{4}$. DEN by itself requires a long time to induce hepatocarcinoma, but the assistance of tumor promoters like $\mathrm{CCl}_{4}$ ensures a shorter time span for the development of liver cancer [10]. $\mathrm{CCl}_{4}$ enhanced hepatocyte proliferation through indirect mechanisms. Essentially, their primary effect is cytotoxicity that eventually triggers compensatory proliferation $[10,46]$.

$\mathrm{DEN}+\mathrm{CCl}_{4}$ application leads to dilatation of central veins and pooling of blood in the sinusoids towards the center of the liver lobule with hemorrhage in hepatic tissues, centrilobular and peripheral necrosis, fibrolamellar carcinoma, pyknotic in the nuclei of hepatic cells, 


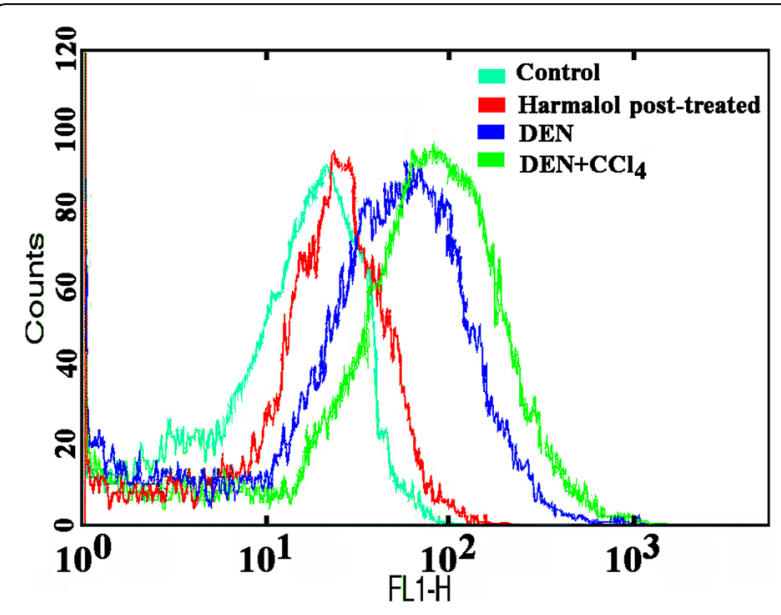

Fig. 9 ROS detection of four liver sections of different groups of control, harmalol post-treated, DEN and DEN+CCl 4 by using DCFHDA, fluorescent probe by flow cytometric analysis

trabecular or sinusoidal pattern, nodule and fibrosis or cirrhosis, and several types of AHF (altered hepatocellular foci). Reports suggested that DEN is hydroxylated by CYP2E1 (cytochrome P450 2E1) in the liver, through an alkylation, to become a biologically active compound. Simultaneous oxidation of $\alpha$ carbon within microsomes induces its DNA damaging activity [47]. Moreover, CYP2E1 had shown to be the principal catalyst for biotransformation of $\mathrm{CCl}_{4}$ into trichloromethyl free radical [48]. Biometabolism of both DNA adduct forming DEN and $\mathrm{CCl}_{4}$ mediated hepatic injury is well documented $[49,50]$. ROS generation from CYP2E1 activity within the hepatocytes contributed to the development of oxidative stress during $\mathrm{DEN}+\mathrm{CCl}_{4}$ exposure, that eventually released stress-specific enzymes in the serum, which is reflected by the marked elevations of liver functional markers such as ALT, AST, LDH, bilirubin, and ALP. Ultimately, abnormal increase in aminotransferases especially ALT reflected liver cell damage [51, 52]. Generally, ALT (SGPT, serum glutamic pyruvic transaminase) and AST (SGOT, serum glutamic oxaloacetic transaminase) are found in the cytoplasm and mitochondria of liver cells in high concentrations but low in blood [53]. However, increased activities of these enzymes in serum are due to increased membrane permeability and leakage into the blood circulation when hepatocytes are injured [54], which is the sign of acute necrosis of liver cells. Increased LDH reflected the formation of tumors in the liver. While ALP, an enzyme, is homogenously distributed mainly in the liver, kidney, and bone tissues, a high level of ALP in serum may be a sign of liver damage. Among all liver function tests, ALP is a helpful screening tool to detect hepatic dysfunction. The mechanism by which alkaline phosphatase reaches the circulation due to the leakage from the bile canaliculi into hepatic sinusoids may result from leaky tight junctions [55]. Elevated serum levels of intestinal alkaline phosphatase have been found in patients with cirrhosis [56]. Thus, ALP has been noted to be an HCC prognostic factor in general. The probable overall clinical steps with the outcome have been postulated schematically in Fig. 10.

The activity of hepatic tissue was further studied by estimation of DNA, RNA, normal serum protein, and cancer biomarker alpha-fetoprotein [57]. Earlier, it was proved by investigators that there is a significant elevation of DNA and RNA levels and a decrease in normal serum protein in cancer cells in response to a carcinogen like $\mathrm{DEN}+\mathrm{CCl}_{4}$ [58-60]. In the present study, harmaloltreated animals showed a significant decrease in DNA and RNA level and restoration of normal serum protein when compared to $\mathrm{DEN}+\mathrm{CCl}_{4}$ group further validating the anti-cancer property of the alkaloid. This effect was probably accompanied by cell cycle arrest which was previously reported by the authors in in vitro HepG2 cells by harmalol [16]. However, an elevated level of alpha-fetoprotein AFP, which is a common diagnostic marker, in the serum has been well documented in HCC and germ cell cancers [60]. It was revealed that elevated level of AFP is observed in the adult animals which are exposed to hepatocarcinogens [60]. There are several reports which show that AFP plays a key role in the regulation of tumor growth and cell differentiation and can stimulate the proliferation of human hepatoma cells possibly through the AFP receptors [61-63]. A significant rise in AFP level observed in $\mathrm{DEN}+\mathrm{CCl}_{4}$ group indicates the presence of $\mathrm{HCC}$ in mice model. Harmalol posttreated group significantly reduced the rise in AFP level when compared with the $\mathrm{DEN}+\mathrm{CCl}_{4}$ group. This reduction in the treatment group of AFP to a near-normal level may be due to inhibitory effect which confirms the chemopreventive therapeutic action of the alkaloid.

Furthermore, an increase in ROS generation or oxidative stress is an important marker of cancer, and in this study, the ROS intensity has been found to increase nearly 4-folds relative to control in the $\mathrm{DEN}+\mathrm{CCl}_{4}$ group. ROS actually creates disruptions in redox balance. Several studies revealed that p53 has an important role in glucose metabolism and redox regulation. Lu et al. had very elaborately showed the mechanistic insights into the relationship between ROS, tumor suppressors, and oncogenes in p53 mouse models. Increased expression of p53 decreased ROS levels by inhibiting glycolysis and promoting NADPH generation [64].

The balance between cell proliferation and apoptosis is essential for the development and structure-function maintenance of normal organs [65]. The occurrence of cancer is supposedly due to the repression of the normal apoptotic process, which caused the imbalance between cell proliferation and apoptosis $[66,67]$. In fact, apoptosis constitutes an 


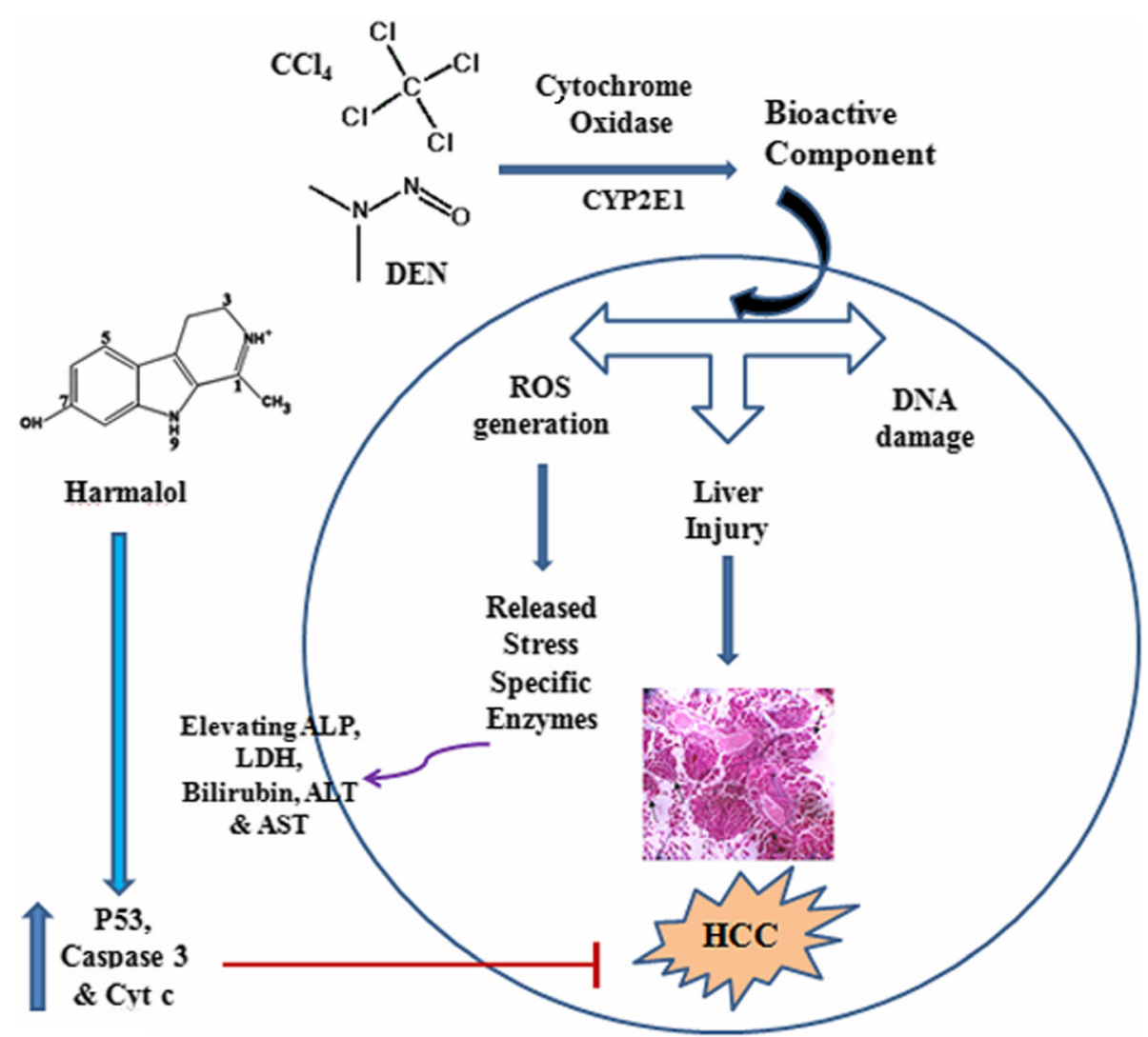

Fig. 10 Schematic representation of the cause of HCC and therapeutic potential of harmalol against HCC

innate tissue defense against carcinogens by preventing the survival of genetically damaged cells. As a result, inhibition of apoptosis has been elucidated as the prevailing mechanism of liver tumor promotion in many rodent studies [68, 69]. This study has highlighted that it is through mitochondrial cytochrome $\mathrm{c}$ release that induces p53 by caspase 3 activation via the intrinsic apoptotic pathway $[68,69]$ which is considered one of the characteristic features of any anti-cancer drug.

\section{Conclusion}

The present findings clearly demonstrate the chemopreventive, dose-dependent activity of natural alkaloid, harmalol, against diethylnitrosamine (DEN) promoted by carbon tetrachloride $\left(\mathrm{CCl}_{4}\right)$-induced hepatocarcinogenesis ( $\left.\mathrm{HCC}\right)$ in mice model based on histological study, enzyme assay, and expression of several molecular markers. It has been found that post-treatment of harmalol $(10 \mathrm{mg} / \mathrm{kg}$ B.W., I.P., per week) for 9 weeks markedly decreased the number of liver tumor nodules, lowered the formation of peripheral and centrilobular necrosis, and helped to regenerate the parenchymal cells in the liver, protecting membrane integrity and decreasing enzyme leakage thereby maintaining the normal histological architect of the liver. It further induces ROS-dependent apoptosis through mitochondrial cytochrome $\mathrm{C}$ release that induces p53 by caspase 3 activation. The study also highlighted that action of harmalol is mostly therapeutic rather than prophylactic. So posttreatment with harmalol would be far better than pretreatment.

The ultimate understanding of these investigations will eventually help to develop more effective chemotherapeutic drugs from the natural product with enhanced efficacy and lower toxicity that can be targeted effectively to canceraffected specific organ for better therapeutic applications.

\section{Supplementary information}

Supplementary information accompanies this paper at https://doi.org/10. 1186/s43094-020-00045-X.

Additional file 1: Figure S1. Diagrammatic representation of in vivo experimental design of hepatocellular carcinoma HCC induction and its treatment with harmalol in Mus musculus. Figure S2. Photographic images of gross liver of different groups of experimental mice. A. Harmalol control for $90 \mathrm{mg} / \mathrm{kg}$ b.w, B. DEN (288mg/kg B.W.) for 9 weeks C. CCl $\left(0.8 \mathrm{ml} / \mathrm{kg}\right.$ b.w) for 4 weeks. D. DEN+CCl 4 (after $1^{\text {st }}$ week), E. $\mathrm{DEN}+\mathrm{CCl} 4$ (after $7^{\text {th }}$ weeks), F. After $14^{\text {th }}$ week of $\mathrm{CCl}_{4}+\mathrm{DEN}$, G. Harmalol pre-treated mice liver.

\section{Abbreviations}

DEN: Diethylnitrosamine; HCC: Hepatocellular carcinoma; AFP: Alphafetoprotein; AHF: Altered hepatocellular foci; ALT: Alanine aminotransferase; ALP: Alkaline phosphatase; AST: Aspartate aminotransferase; 
CYP2E1: Cytochrome P450 2E1; DCFH-DA: Dichloro fluorescence diacetate; H\&E: Hematoxylin and eosin; LDH: Lactate dehydrogenase; ROS: Reactive oxygen species

\section{Acknowledgements}

The authors are thankful to PRG University of Kalyani, 2020-21, and Animal Ethical Committee, University of Kalyani, and are grateful to Dr. Partho Pratim Chakrabarti, Principal Scientist, ICAR-CIFA, Field Station Kalyani, for providing the light microscopic facility.

\section{Authors' contributions}

SS did the in vivo experiments, conducted the biological assays, and analyzed the data; $\mathrm{PB}$ and TG have equal contributions and assisted in the experiments; and KB designed the research and analyzed, compiled, and reviewed the data and wrote the manuscript. The authors read and approved the final manuscript.

\section{Funding}

SS is supported by DST-SERB-NPDF (file no. PDF/2017/000398), 2018-20, and KB is indebted to DST-RFBR, 2017-19 (DST/INT/RUS/RFBR/P-254), and the Council of Scientific and Industrial Research (CSIR), Government of India for the financial support (Ref. no. 37 (1538)/12/EMR-II). PB is supported by s grant from the University of Kalyani. TG is supported by a grant from UGC, Govt. of India.

\section{Availability of data and materials}

All data have been included in the text and supplementary file.

\section{Ethics approval and consent to participate}

Animal care and all experimental protocols were performed according to the health criteria of laboratory animals and the study was conducted after obtaining Institutional Animal Ethical Committee clearance under the registration no. 892/GO/Re/S/01/CPCSEA, dated 20 April 2014-28 April 2019, University of Kalyani. The animals were kept under quarantine for 1 week prior to experiment.

All co-authors and corresponding author have their consent to participate.

\section{Consent for publication}

All co-authors and corresponding author have their consent for publication in this journal and authors have acknowledged their respective funding agencies.

\section{Competing interests}

No competing financial interests exist. The authors declare no conflict of interest.

The work embodied in this manuscript has not been published previously or is under consideration for publication in any other journal.

\section{Author details}

'Department of Zoology, University of Kalyani, Nadia, West Bengal 741235, India. ${ }^{2}$ Present Address: Division of Molecular Medicine, Bose Institute, Kolkata 700054, India.

\section{Received: 16 February 2020 Accepted: 10 June 2020}

Published online: 01 July 2020

\section{References}

1. Tsukuma H, Tanaka H, Wakiko A, Oshima A (2005) Liver cancer and its prevention. Asian Pac J Cancer Prev 6:244-250 https://www.ncbi.nIm.nih. gov/pubmed/16235981

2. Karin M, Dhar D (2016) Liver carcinogenesis: from naughty chemicals to soothing fat and the surprising role of NRF2. Carcinogenesis 37: 541-546 https://doi:10.1093/carcin/bgw060

3. Farber $E$ (1984) The multistep nature of cancer development. Cancer Res 44: 4217-4223 https://www.ncbi.nlm.nih.gov/pubmed/6467183

4. Bartsch H, Hietanen E, Malaveille C (1989) Carcinogenic nitrosamines: free radical aspects of their action. Free Radic Biol Med 7:637-644. https://doi. org/10.1016/0891-5849(89)90144-5 https://www.ncbi.nlm.nih.gov/ pubmed/2695407
5. Farber JL, Gerson RJ (1984) Mechanisms of cell injury with hepatotoxic chemicals. Pharmacol Rev 36:71S-75S https:/www.ncbinlm.nih.gov/ pubmed/6382357

6. Tomatis L, Agthe C, Bartsch $H$, Huff J, Montesano R, Saracci R, Walker E, Wilbourn J (1978) Evaluation of the carcinogenicity of chemicals: a review of the Monograph Program of the International Agency for Research on Cancer (1971 to 1977). Cancer Res 38:877 https://cancerres.aacrjournals.org/ content/38/4/877

7. Bosnir J, Smit Z, Puntarić D, Horvat T, Klarić M, Simić S, Zorić I (2003) Presence of $\mathrm{N}$-nitrosamines in canned liver patty, Department of Health Ecology, Public Health Institute, Zagreb, Croatia. Coll Antropo 27:67-70 https://www.ncbi.nlm.nih.gov/pubmed/12955894

8. Chuang SE, Kuo ML, Hsu CH, Chen CR, Lin JK, Lai GM, Hsieh CY, Cheng AL (2000) Curcumin-containing diet inhibits diethylnitrosamine-induced murine hepatocarcinogenesis. Carcinogenesis 21:331-335 https:/www.ncbinlm.nih. gov/pubmed/10657978

9. Rajewsky MF, Dauber W, Frankenberg H (1966) Liver carcinogenesis by diethylnitrosamine in the rat. Science 152:83-85 https://www.ncbi.nlm.nih. gov/pubmed/5910014

10. Sakurai T, Maeda S, Chang L, Karin M (2006) Loss of hepatic NF-kappa B activity enhances chemical hepatocarcinogenesis through sustained c-Jun N-terminal kinase 1 activation. Proc Natl Acad Sci U S A 103:10544-10551 https://doi.org/10.1073/pnas.0603499103

11. Weisburger EK (1977) Carcinogenicity studies on halogenated hydrocarbons. Environ Health Perspect 21:7-16 https://dx.doi.org/10.1289\%2Fehp.77217

12. Yoshioka H, Usuda H, Fukuishi N, Nonogaki T, Onosaka S (2016) Carbon tetrachloride-induced nephrotoxicity in mice is prevented by pretreatment with zinc sulfate. Biol Pharm Bull 39:1042-1046

13. Nakatani T, Roy G, Fujimoto N, Asahara T, Ito A (2001) Sex hormone dependency of diethylnitrosamine-induced liver tumors in mice and chemoprevention by leuprorelin. Jpn J Cancer Res 92:249-256 https://www. ncbi.nlm.nih.gov/pubmed/11267934

14. Lamchouri F, Settaf A, Cherrah Y, Zemzami M, Lyoussi B, Zaid A, Atif N, Hassar M (1999) Antitumour principles from Peganum harmala seeds. Therapie 54:753-758 https://www.ncbinlm.nih.gov/pubmed/10709452

15. Diwan SY (2013) Effect of Peganum harmala methanol extract on liver and kidney of mice administered MTX drug. J Al-Nahrain University 16:161-166 https://pdfs.semanticscholar.org/9600/20fe57597508731fd2053a42d816bb02 $833 d$

16. Sarkar S, Bhattacharjee P, Bhadra K (2016) DNA binding and apoptotic induction ability of harmalol in HepG2: Biophysical and biochemical approaches. Chem Biol Interact 258:142-152 https://doi.org/10.1016/j.cbi. 2016.08.024

17. Sarkar S, Pandya P, Bhadra K (2014) Sequence specific binding of beta carboline alkaloid harmalol with deoxyribonucleotides: binding heterogeneity, conformational, thermodynamic and cytotoxic aspects. PLoS One 9:1-14 https://doi.org/10.1371/journal.pone.0108022

18. Bhattacharjee P, Sarkar S, Pandya P, Bhadra K (2016) Targeting different RNA motifs by beta carbolinealkaloid, harmalol: a comparative photophysical, calorimetric and molecular docking approach. J Biomol Struct Dyn 34:27222740 https://www.ncbi.nlm.nih.gov/pubmed/26629671

19. Sarkar S, Bhadra K (2014) Binding of alkaloid harmalol to DNA: photophysical and calorimetric approach. J Photochem Photobiol B Biol 130:272-280 https://www.ncbi.nlm.nih.gov/pubmed/24368411

20. Hua S, Linghong Y, Huailing W, Gengtao L (2012) A novel antihepatitis drug, bicyclol, prevents liver carcinogenesis in diethylnitrosamine-initiated and phenobarbital-promoted mice tumor model. J Biomed Biotech, ID- 584728 1-9, doi:https:/doi.org/10.1155/2012/584728, https:/doi.org/10.1155/2012/584728

21. Velasco-Loyden G, Pérez-Martínez L, Vidrio-Gómez S, Isael Pérez-Carreón J, Chagoya de Sánchez V (2017) Cancer chemoprevention by an adenosine derivative in a model of cirrhosis-hepatocellular carcinoma induced by diethylnitrosamine in rats. Tumor Biol 1-12.

22. Kind PRH, King EJ (1954) Estimation of plasma phosphatase by determination of hydrolysed phenol with amino-antipyrine. J Clin Pathol 7: 322-326 https://dx.doi.org/10.1136\%2Fjcp.7.4.322

23. Cabaud PG, Wroblewski F (1958) Colorimetric measurement of lactic dehydrogenase activity of body fluids. Am J Clin Pathol 30:234-236 https:// doi.org/10.1093/ajcp/30.3.234

24. Reitman S, Frankel S (1957) A colorimetric method for the determination of serum glutamic oxalacetic and glutamic pyruvic transaminases. Am J Clin Pathol 28:56-63 https://doi.org/10.1093/ajcp/28.1.56 
25. Moss DW, Henderson AK (1994) Clinical enzymology. In: Burtis CA, Ashwood ER (eds) Teitz textbook of clinical chemistry, 3rd ed. W.B. Saunders, Philadelphia

26. Wenger WC. Lott JA, Kaplan LA, Pesce AJ (1994) Enzymes, In Clinical chemistry. Theory, Analysis and Co-relation. Mosby C.V., Toronto

27. Kaplan JR, Manuck SB, Clarkson TB, Lusso FM, Taub DM, Miller EW (1983) Social stress and atherosclerosis in normocholesterolemic monkeys. Science 220:733-735 https://doi.org/10.1126/science.6836311

28. Tietz NW, Rinker AD, Shaw LM (1983) IFCC methods for the measurement of catalytic concentration of enzymes. Part 5. IFCC method for alkaline phosphatase (orthophosphoric-monoester phosphohydrolase, alkaline optimum, EC 3.1.3.1). IFCC Document Stage 2, Draft 1, 1983-03 with a view to an IFCC Recommendation. J Clin Chem Clin Biochem 21:731-748

29. Giles KW, Myres A (1965) An improved diphenylamine method for the estimation of deoxyribonucleic acid. Nature 206:4979 https://www.nature. com/articles/206093a0

30. Burton K (1956) A study of the conditions and mechanism of the diphenylamine reaction for the colorimetric estimation of deoxyribonucleic acid. Biochem J 62:315-323. https://doi.org/10.1042/bj0620315 https://dx. doi.org/10.1042\%2Fbj0620315

31. Almog R, Shirey TL (1978) A modified orcinol test for the specific determination of RNA. Anal Biochem 91:130-137 https://doi.org/10.1016/ 0003-2697(78)90823-0

32. Blobel G, Potter VR (1968) Distribution of radioactivity between the acidsoluble pool and the pools of RNA in the nuclear, nonsedimethable and ribosome fractions of rat liver after a single injection of lebaled orotic acid. Biochim Biophys Acta 166:48-57 https://doi.org/10.1016/00052787(68)90489-9

33. Lowry OH, Rosebrough NJ, Farr AL, Randall RJ (1951) Protein measurement with the Folin phenol reagent. J Biol Chem 193:265-275 https://www.ncbi. nlm.nih.gov/pubmed/14907713

34. Alarami AMJ (2015) Histopathological changes in the liver and kidney of albino mice on exposure to insecticide, dimethoate. Int J Curr Microbiol App Sci 4:287-300 https://www.ijcmas.com/vol-4-7/Ateeq.\%20M.\%20J.\%2 OAlarami.pdf

35. Lee C (2007) Protein extraction from mammalian tissues. Methods Mol Bio 362:385-389 https://doi.org/10.1007/978-1-59745-257-1_29

36. Severgnini $M$, Sherman J, Sehgal A, Jayaprakash NK, Aubin J, Wang G, Zhang L, Peng CG, Yucius K, Butler J, Fitzgerald K (2012) A rapid two-step method for isolation of functional primary mouse hepatocytes: cell characterization and asialoglycoprotein receptor based assay development. Cytotechnology 64:187-195 https://dx.doi.org/10.1007\%2Fs10616-011-9407-

37. Reh BD, Fajen JM (1996) Worker exposures to nitrosamines in a rubber vehicle sealing plant. Am Ind Hyg Assoc J 57:918-923 https://doi.org/10. 1080/15428119691014431

38. Hussain T, Siddiqui HH, Fareed S, Vijayakumar M, Rao CV (2012) Evaluation of chemopreventive effect of Fumaria indica against $\mathrm{N}$-nitrosodiethylamine and $\mathrm{CCl}_{4}$-induced hepatocellular carcinoma in Wistar rats. Asian Pac J Trop Med 5:623-629 https://doi.org/10.1016/S1995-7645(12)60128-X

39. Newsholme SJ, Fish CJ (1994) Morphology and incidence of hepatic foci of cellular alteration in Sprague-Dawley rats. Toxicol Pathol 22:524-527 https:// doi.org/10.1177/019262339402200507

40. Mohan H (2010) Text book of pathology, 6th ed., Jaypee Brothers Medical Publishers (P)Ltd.

41. Das J, Das S, Samadder A, Bhadra K, Khuda-Bukhsh AR (2012) Poly (lactideco-glycolide) encapsulated extract of Phytolacca decandra demonstrates better intervention against induced lung adenocarcinoma in mice and on A549 cells. Eur J Pharm Sci 47:313-324 https://doi.org/10.1016/j.ejps.2012.06. 018

42. Saha S, Sikdar S, Mukherjee A, Bhadra K, Boujedainic N, Khuda-Bukhsh AR (2013) Ethanolic extract of the Goldenseal, Hydrastis canadensis, hasdemonstrable chemopreventive effects on HeLa cells in vitro drug-DNA interaction with calf thymus DNA as target. Environ Toxicol Pharmacol 36: 202-214 https://doi.org/10.1016/j.etap.2013.03.023

43. Chatterjee S, Mallick S, Buzzetti F, Fiorillo G, Syeda TM, Lombardi P, Das Saha K, Kumar GS (2015) New 13-pyridinealkyl berberine analogues intercalate to DNA and induce apoptosis in HepG2 and MCF-7 cells through ROS mediated p53 dependent pathway: biophysical, biochemical and molecular modeling studies. RSC Adv 5:90632-90644 https://doi.org/10.1039/ C5RA17214D
44. Jaganathan SK, Mazumdar A, Mondhe D, Mandal M (2011) Apoptotic effect of eugenol in human colon cancer cell lines. Cell Biol Int 35:607-615 https://doi.org/10.1042/CBI20100118

45. Elmore S (2007) Apoptosis: a review of programmed cell death. Toxicol Pathol 35:495-516 https://doi.org/10.1080/01926230701320337

46. Paul A, Das S, Das J, Samadder A, Khuda-Bukhsh AR (2013) Cytotoxicity and apoptotic signaling cascade induced by chelidonine-loaded PLGA nanoparticles in HepG2 cells in vitro and bioavailability of nano-chelidonine in mice in vivo. Toxicol Lett 222:10-22 https://doi.org/10.1016/j.toxlet.2013. 07.006

47. Yamazaki H, Oda Y, Funae $Y$ (1992) Participation of rat liver cytochrome P450 2E1 in the activation of N-nitrosodimethylamine and Nnitrosodiethylamine to products genotoxic in an acetyltransferaseoverexpressing Salmonella typhimurium strain (NM2009). Carcinogenesis 13: 979-985 https://doi.org/10.1093/carcin/13.6.979

48. Kujawska M (2009) Protective effect of red beetroot against carbon tetrachloride- and N-nitrosodiethylamine-induced oxidative stress in rats. J Agric Food Chem 57:2570-2575 https://doi.org/10.1021/jf803315d

49. Ravid A, Koren R (2003) The role of reactive oxygen species in the anticancer activity of vitamin D. Vitamin $d$ analogs in cancer prevention and aherapy, 164, pp 357-367, Editors Reichrath J, Tilgen W, Friedrich M, doi https://doi.org/10.1007/978-3-642-55580-0, https://doi.org/10.1007/978-3642-55580-0_26

50. Recknagel RO, Glende EA Jr (1973) Carbon tetrachloride hepatotoxicity: an example of lethal cleavage. CRC Crit Rev Toxicol 2:263-297 https://doi.org/ 10.3109/10408447309082019

51. Chinelo N, Nkechi NF, Onyinyechi NR, Uzoma NO (2018) Effect of methanol extract of Synsepalum dulcificum pulp on some biochemical parameters in albino rats. Academic J Article Number: E78B526, A Paper Presented at the WANNPRES 9th Sub-Regional Scientific Meeting, University of Nigeria, Nsukka, Enugu State, Nigeria

52. Mayne PD (1998) Clinical chemistry diagnosis and treatment, 6th ed. London,UK: Arnold International 199

53. Aliyu $R$, Adebavo AH, Gatsing D, Garba $\mathbb{H}$ (2007) The effects of ethanolic leaf extract of Commiphora africana (Burseraceae) on rat liver and kidney functions. J Pharmacol Toxicol 2:373-379 https://doi.org/10.3923/jpt.2007.373.379

54. Maxine MB (1978) Outline of veterinary clinical pathology. IOWA, USA: University Press 229.

55. Daniel SP, Marshall MK (1999) Evaluation of the liver: laboratory tests. Schiff's diseases of the liver, 8th edn. USA; JB Lippincott publications, 205-239.

56. Warnes TW, Hine P, Kay G (1977) Intestinal alkaline phosphatase in the diagnosis of liver disease. Gut 18:274-279

57. Das BK, Koti BC, Gadad PC (2016) Role of Lycopersicon esculentum in diethylnitrosamine-induced and phenobarbital-promoted hepatocellular carcinoma. Indian Journal of Health Sciences 9:147-152

58. Sadik NA, El-Maraghy SA, Ismail MF (2008) Diethylnitrosamine-induced hepatocarcinogenesis in rats: Possible chemoprevention by blueberries. Afr J Biochem Res 2:81-87

59. Levy J, Sharoni Y (2004) The functions of tomato lycopene and its role in human health. Herb Gram 62:50-56

60. Kashala LO, Kalengayi MM, Essex M (1992) Alpha-fetoprotein synthesis in human hepatocellular carcinoma: correlation with hepatitis B surface antigen expression. Cancer Investig 10:513-522

61. Dudich E, Semenkova L, Gorbatova E, Dudich I, Khromykh L, Tatulov E et al (1998) Growth-regulative activity of human alpha-fetoprotein for different types of tumor and normal cells. Tumour Biol 19:30-40

62. Li MS, Li PF, Yang FY, He SP, Du GG, Li G (2002) The intracellular mechanism of alpha-fetoprotein promoting the proliferation of $\mathrm{NIH} 3 \mathrm{~T} 3$ cells. Cell Res 12:151-156

63. Glory MD, Thiruvengadam D (2012) Potential chemopreventive role of chrysin against $\mathrm{N}$-nitrodiethylamine-induced hepatocellular carcinoma in rats. Biomed Prev Nutr 2:106-112

64. Lu W, Ogasawara MA, Huang P (2007) Models of reactive oxygen species in cancer. Drug Discov Today Dis Model 4:67-73 https://dx.doi.org/10.1016\%2 Fj.ddmod.2007.10.005

65. Kanzler S, Galle PR (2000) Apoptosis and the liver. Semin Cancer Biol 10: 173-184. https://doi.org/10.1006/scbi.2000.0318

66. Park YN, Chae KJ, Kim YB, Park C, Theise N (2001) Apoptosis and proliferation in hepatocarcinogenesis related to cirrhosis. Cancer 92:27332738 https://doi.org/10.1002/1097-0142(20011201)92:11\%3C2733:.:aidcncr10126\%3E3.0.co;2-5 
67. Bursch W, GrasI-Kraupp B, Wastl U, Hufnagl K, Chabicovsky M, Taper H, Schulte-Hermann R (2004) Role of apoptosis for mouse liver growth regulation and tumor promotion: comparative analysis of mice with high (C3H/He) and low (C57Bl/6 J) cancer susceptibility. Toxicol Lett 149:25-35 https://doi.org/10.1016/j.toxlet.2003.12.018

68. Li Y, Chen L, Chan TH, Liu M, Kong KL, Qiu JL, Li Y, Yuan YF, Guan XY (2013) SPOCK1 is regulated by CHD1L and blocks apoptosis and promotes HCC cell invasiveness and metastasis in mice. Gastroenterology 144:179-191 https://doi.org/10.1053/j.gastro.2012.09.042

69. Schuler M, Wetzel EB, Goldstein JC, Fitzgerald P, Green DR (2000) p53 induces apoptosis by caspase activation through mitochondrial cytochrome c release. J Biol Chem 275:7337-7342 https://doi.org/10.1074/jbc.275.10.7337

\section{Publisher's Note}

Springer Nature remains neutral with regard to jurisdictional claims in published maps and institutional affiliations.

\section{Submit your manuscript to a SpringerOpen ${ }^{\circ}$ journal and benefit from:}

- Convenient online submission

- Rigorous peer review

- Open access: articles freely available online

High visibility within the field

- Retaining the copyright to your article

Submit your next manuscript at $\boldsymbol{\nabla}$ springeropen.com 